\title{
Nieetyczne zachowania w relacjach między przedsiębiorstwami jako zagrożenie dla realizacji Celów Zrównoważonego Rozwoju i wynikających z nich zadań
}

\section{Streszczenie}

Artykuł ma charakter studium teoretycznego, choć odwołuje się również do wyników badań empirycznych. Bodźcem do jego napisania stały się opinie o niewystarczającym stopniu zaawansowania realizacji Celów Zrównoważonego Rozwoju ONZ. W artykule przyjęto założenie, że niewystarczające zaawansowanie może wynikać w pewnym stopniu z możliwych zachowań nieetycznych dużych przedsiębiorstw podejmowanych $\mathrm{w}$ trakcie relacji z mniejszymi podmiotami, które nominalnie mogłyby służyć realizacji wybranych Celów Zrównoważonego Rozwoju. Jednym z celów artykułu jest zidentyfikowanie sytuacji sprzyjających nieetycznym zachowaniom przedsiębiorstw. W tekście określono, na czym ogólnie polegają zachowania nieetyczne przedsiębiorstw oraz wskazano, na czym mogą polegać zachowania nieetyczne przedsiębiorstw podejmowane w związku z realizacją zadań służących osiąganiu Celów Zrównoważonego Rozwoju. Innym celem artykułu było zidentyfikowanie cech małych i średnich przedsiębiorstw sprzyjających podejmowaniu wobec nich zachowań nieetycznych przez podmioty nawiązujące z nimi relacje. Cechy te wskazano, odwołując się do wyników badań empirycznych. Na tej podstawie przedstawiono, co mniejsze przedsiębiorstwa mogą przedsięwziąć, by być

Dr hab. Bogusław Gulski, pracownik Katedry Zarządzania w Instytucie Nauk o Zarządzaniu i Jakości na Wydziale Ekonomicznym Uniwersytetu Marii Curie-Skłodowskiej w Lublinie; e-mail: boguslaw.gulski@mail.umcs.pl; ORCID: 0000-0002-2681-7815. 
w mniejszym stopniu narażonymi na zachowania nieetyczne w trakcie relacji, co może sprzyjać realizacji Celów Zrównoważonego Rozwoju.

Słowa kluczowe: zachowania nieetyczne przedsiębiorstw, Cele Zrównoważonego Rozwoju, relacje międzyorganizacyjne, etyka biznesu, etyka w biznesie

\section{Wprowadzenie}

We wrześniu 2015 roku odbył się szczyt Agendy Zrównoważonego Rozwoju 2030, w którym udział wzięło ponad 100 głów państw i szefów rządów, a także przedstawiciele grup religijnych, biznesu i społeczeństwa obywatelskiego. Podczas szczytu przyjęto dokument „Przekształcanie naszego świata: Agenda na Rzecz Zrównoważonego Rozwoju - 2030". Zawarto w nim 17 Celów Zrównoważonego Rozwoju (ang. Sustainable Development Goals - SDGs; dalej: CZR). Są one ukierunkowane globalnie, zaś ich realizacja ma być monitorowana przez szereg wskaźników.

Jednak osiągnięcie celów rozwojowych nie jest oczywiste. Opublikowane przez Organizację Narodów Zjednoczonych (ONZ) w 2017 roku trzy raporty z realizacji CZR sygnalizowały trudności już w pierwszych latach realizacji, a Sekretarz Generalny ONZ stwierdził: „Wdrażanie rozpoczęło się, a zegar tyka. Ten raport pokazuje, że poziom postępu w wielu obszarach jest znacznie wolniejszy niż potrzeba, aby osiągnąć cele do 2030 roku" 1 .

Zaniepokojenie stopniem realizacji CZR wyrażają również m.in. przedstawiciele związków zawodowych. Uczestnicy grupy roboczej ds. Agendy 2030 i CZR działający w ramach Europejskiej Konfederacji Związków Zawodowych zauważyli, że zaangażowanie rządów ich państw w realizację CZR jest niskie².

Punktem wyjścia dla rozważań zawartych w artykule jest teza, że większe i/lub silniejsze przedsiębiorstwa, angażując się w relacje z mniejszymi podmiotami, mogą przyczyniać się do realizacji CZR, ale także mogą utrudniać ich realizację. W przeprowadzonych rozważaniach odwołano się do nurtu krytycznego w zarządzaniu (ang. Critical Management Studiem - CMS), a w szczególności do założenia denaturalizacji (ang. denaturalization). Jest to strategia badawcza ukierunkowana na kwestionowanie uznawanych za naturalne i oczywiste elementów rzeczywistości organizacyjnej. Na gruncie nurtu krytycznego dostrzega się, że niektóre praktyki organizacyjne podlegają procesom naturalizacji przez odniesienie ich do kategorii

1 Progress Towards the Sustainable Development Goals, Raport Sekretarza Generalnego ONZ E/2017/66 z 11 maja 2017 r. Pobrane z: www.un.org/development/desa/publications/sdg-report-2017.html (11.10.2019).

2 II posiedzenie Grupy Roboczej EKZZ ds. Agendy 2030 i celów zrównoważonego rozwoju ONZ, opzz, Aktualności, Porozumienie, Wydarzenia/25 stycznia 2019. Pobrane z: www.kadra.org.pl/grupa-robocza-ekzz-ds-zrownowazonego-rozwoju (22.06.2020). 
konieczności czy nawet natury, co uodparnia je na krytykę. Elementami organizacji, które podlegają silnej naturalizacji, są m.in. niektóre wartości, np. chciwość czy rywalizacja, z punktu widzenia funkcjonalizmu postrzegane jako neutralne normatywnie, a nawet jako pożądane stany rzeczy (Zawadzki, 2014, s. 30-31).

Można sądzić, że jednym z czynników powodujących niezadowalający stopień realizacji CZR jest fakt, że wiele zachowań przedsiębiorstw podejmowanych jest pod wpływem ideologii wartości dla akcjonariuszy, która motywuje przedsiębiorstwa m.in. do zatrzymywania jak największej wartości, która później trafia do ich akcjonariuszy. Natomiast aktywne włączenie się dużych przedsiębiorstw w realizację niektórych CZR może grozić brakiem wzrostu zatrzymanej wartości. Dlatego mogą one stanąć przed alternatywą: włączyć się w realizację CZR, i tym samym „ułatwić życie” małym i średnim przedsiębiorstwom, czy skupić się na realizacji własnych celów? Drugi z wyborów jest atrakcyjny, tym bardziej że względna słabość mniejszych podmiotów może ułatwić zwiększenie wartości zatrzymywanej przez duże przedsiębiorstwa w trakcie relacji z nimi. Niektóre z zachowań skutkujących wzrostem wartości zatrzymanej przez duże podmioty z pewnością można uznać za nieetyczne. Takie zachowania są przedmiotem zainteresowania autora artykułu. W kontekście wartości ważną wydaje się opinia:

Firma jednak powinna próbować popierać etyczne decyzje nie tylko dlatego, że po prostu jest to właściwe postępowanie, ale również dlatego, że leży to w jej własnym, dobrze pojmowanym, długofalowym interesie. Nieetyczne zachowanie może bowiem powodować poważne koszty w sferze osobowej, organizacyjnej i społecznej (Lambin, 2001, s. 76).

Do kosztów zachowań nieetycznych należy również zaliczyć m.in. zagrożenie dla legitymizacji przedsiębiorstwa oraz dla realizacji CZR.

Cel niniejszego artykułu jest dwojaki:

(1) zidentyfikowanie sytuacji sprzyjających nieetycznym zachowaniom przedsiębiorstw, do których może dochodzić w związku z CZR, które zarazem stanowią potencjalne zagrożenie dla realizacji tych celów;

(2) zidentyfikowanie tych cech małych i średnich przedsiębiorstw, które ułatwiają dużym podmiotom podejmowanie wobec nich zachowań nieetycznych, skutkujących utratą wartości przez małe i średnie przedsiębiorstwa.

Ze wskazanych celów wynika struktura artykułu. W części pierwszej rozważono niektóre zagadnienia etyczne występujące w relacjach między przedsiębiorstwami. Odniesiono się do norm moralnych, w szczególności do sprawiedliwości. Pozwoliło to określić podstawowe cechy zachowań nieetycznych przedsiębiorstw, czyli zidentyfikować definiens zachowań nieetycznych przedsiębiorstw. W kolejnej części zaprezentowano podstawy generowania i zatrzymywania wartości przez 
przedsiębiorstwa. W części trzeciej wymieniono te CZR, o których można sądzić, że przyczyniają się do poprawy sytuacji małych i średnich przedsiębiorstw, a także dokonano analizy zadań służących ich realizacji. Kolejno zidentyfikowano sytuacje sprzyjające zachowaniom nieetycznym oraz opisano szereg takich zachowań przedsiębiorstw. Na koniec zidentyfikowano te cechy małych i średnich przedsiębiorstw, które ułatwiają podejmowanie wobec nich zachowań nieetycznych oraz ogólnie wskazano, w jaki sposób mniejsze przedsiębiorstwa mogą ograniczyć zagrożenie zachowaniami nieetycznymi.

$\mathrm{W}$ artykule wykorzystano studia literaturowe oraz odwołano się do opublikowanych wyników badań empirycznych.

\section{Podejście etyczne do relacji między przedsiębiorstwami}

Zdarzenia historyczne i obserwacja współczesności prowadzą do konstatacji, że najczęściej wielkie przedsięwzięcia ludzkości napędzają chciwość, strach czy potrzeba chwały. Z tym poglądem współgra formułowana w niektórych środowiskach opinia, iż głównym powodem kryzysu finansowego, który rozpoczął się w 2008 roku, były działania nieetyczne. Ale, jak optymistycznie stwierdził Paul H. Dembinski (2012), jeżeli w gospodarce „zagości” etyka, kapitalizm stanie się bardziej moralny, a świat będzie zdrowszy. Kierując się takim samym optymizmem, można sądzić, że obecność etyki w trakcie realizacji CZR spowoduje, że ich osiągnięcie będzie bardziej skuteczne. Wynika stąd potrzeba określenia, jakie zachowania podmiotów funkcjonujących w gospodarce można uznać za etyczne, jakie zaś za nieetyczne.

Wskazuje się dwa podstawowe znaczenia terminu „norma moralna”: (1) podstawowa zasada etyczna, wokół której buduje się określony system aksjologiczny; (2) dyrektywa nakazująca lub zakazująca określonego postępowania (Machura, 2011). W dalszej części rozważań odwołano się do drugiego ze wskazanych znaczeń terminu „norma moralna”. Wśród norm moralnych ważną rolę odgrywają normy strzegące sprawiedliwości (np. bądź zawsze sprawiedliwy, odpłacaj dobrem, nie czyń zła, nie doprowadzaj do roszczeń nieuzasadnionych lub zbytnio rozszerzonych).

Rozważając z etycznego punktu widzenia relacje między przedsiębiorstwami, za punkt wyjścia należy przyjąć zasadę, że korzystanie z rzeczy, w szczególności z zasobów, przynosi pewne dochody nazywane pożytkami. Są to dochody, które przynosi prawo. Dotyczy to również efektów współdziałania przedsiębiorstw. Zasady sprawiedliwości w relacjach między przedsiębiorstwami powinny wyrażać się w regułach prawa. Ważność sprawiedliwości podziału wynika z pojawiania się nowej 
wartości (np. wartość wytworzona przez współdziałające przedsiębiorstwa), która musi być podzielona, w konsekwencji czego konieczne jest określenie, w jaki sposób mają być dzielone korzyści ze współpracy (Young, 2003, s. 16 i nn.).

Dla oceny relacji między przedsiębiorstwami, z punktu widzenia etyki, użyteczne wydaje się podejście Dembinskiego (2012), który, analizując systemy społeczne, postawił tezę, że przetrwanie każdego systemu zależy od utrzymania minimalnego stopnia spójności między odmiennymi logikami występującymi w jego obrębie. Taki stan ma miejsce, gdy określona zasada organizacji jest stosowana przez wszystkie komponenty systemu. Jednak w każdym systemie społecznym, nawet jeśli sprawia wrażenie, iż znajduje się w stanie równowagi, dochodzi do tarć między rywalizującymi zasadami organizacji, które stale kwestionują dominującą. Dlatego nie można mieć pewności, że system pozostanie spójny lub stabilny. Dembinski (2012) wyjaśnia, że dla tych, którzy postrzegają różne podsystemy jako oddzielne, każdy z nich ma swoją specyficzną etykę. W związku z tym, jeśli zostanie zaakceptowana ważność lub użyteczność dla społeczeństwa danego podsystemu, jedyną kwestią etyczną dla jego uczestników jest to, jak sprawić, by to on sprawnie funkcjonował. W takiej sytuacji (postrzeganie podsystemów jako oddzielnych) etyka jest endogeniczna dla każdego podsystemu. Jest to sytuacja właściwa dla etyki biznesu. Jedynym kryterium oceny tego, co jest dobre, a co złe, jest to, czy ułatwione jest prawidłowe funkcjonowanie podsystemu. Zgodnie z tym poglądem na etykę każdy system, który działa, jest etyczny.

Natomiast ci, którzy postrzegają system społeczny jako spójną całość rządzoną przez dominującą logikę, odrzucają taki pogląd. Uważają, że etyka jest egzogeniczna dla różnych podsystemów. Wyróżnia się dwie odmiany tej teorii: (1) pogląd, że każdy system społeczny rozwija swoją własną, specyficzną etykę, której celem jest utrzymanie funkcjonowania systemu; (2) pogląd, że źródło etyki leży poza wszystkimi systemami społecznymi i organizacjami, które są po prostu ramami, w których ludzie stale dążą do dobrego życia. Taki pogląd jest właściwy dla zwolenników etyki w biznesie. Jakkolwiek różnica między określeniami etyka biznesu i etyka w biznesie zdaje się być zaledwie semantyczną, niesie za sobą fundamentalne różnice w poglądach na cele etyki (Dembinski, 2012). W drugi z wymienionych nurtów wpisała się Elaine Sternberg, stwierdzając, że etyka w biznesie jest uniwersalna, ponieważ uniwersalne są leżące u jej podstawy zasady etyczne (Sternberg, 1998, s. 95).

Na potrzeby prowadzonych w dalszej części artykułu analiz przyjęto, że parę pozostających w relacjach przedsiębiorstw można potraktować jako system, którego składniki (przedsiębiorstwa) mogą kierować zasadami etyki biznesu lub etyki w biznesie. 
Odmienność między etyką biznesu a etyką w biznesie Dembinski (2012) wykorzystał do zidentyfikowania podstawowych obszarów konfliktów, jakie mają miejsce we współczesnej gospodarce. Niektóre z nich przedstawiono w tabeli 1.

Tabela 1. Postrzeganie wybranych obszarów konfliktów we współczesnej gospodarce z punktu widzenia etyki biznesu i etyki w biznesie

\begin{tabular}{|c|c|c|c|}
\hline \multirow[b]{2}{*}{ Lp. } & \multirow[b]{2}{*}{ Obszar konfliktu } & \multicolumn{2}{|c|}{ Punkt widzenia } \\
\hline & & Etyki biznesu & Etyki w biznesie \\
\hline 1. & Wynagrodzenie & $\begin{array}{l}\text { Problemem jest sposób ustalania } \\
\text { wynagrodzeń. } \\
\text { Sprawnie funkcjonujące rynki traktowane } \\
\text { są jako to wszystko, co jest potrzebne, aby } \\
\text { zapewnić realne ceny }\end{array}$ & $\begin{array}{l}\text { Dyskusja tylko o cenie } \\
\text { jest częścią wysiłków, by } \\
\text { pominąć takie aspekty, jak } \\
\text { uznanie wynagrodzenia } \\
\text { za niesprawiedliwe czy } \\
\text { nieuzasadnione z powodu ich } \\
\text { wpływu na spójność społeczną }\end{array}$ \\
\hline 2. & $\begin{array}{c}\text { Natura } \\
\text { przedsiębiorstw }\end{array}$ & $\begin{array}{l}\text { Przedsiębiorstwo jest instrumentem } \\
\text { stosowanym przez właścicieli kapitału do } \\
\text { maksymalizowania ich zwrotu z inwestycji }\end{array}$ & $\begin{array}{l}\text { Przedsiębiorstwo służy } \\
\text { społeczności interesariuszy } \\
\text { dążących do wspólnych celów }\end{array}$ \\
\hline 3. & Konflikty interesów & $\begin{array}{l}\text { Konflikty interesów mogą zostać } \\
\text { wyeliminowane przez konkurencję oraz } \\
\text { sprawnie działające rynki i obieg informacji, } \\
\text { to problem raczej techniczny niż etyczny }\end{array}$ & $\begin{array}{l}\text { Konflikty interesów nie mogą } \\
\text { zostać wyeliminowane, ale mogą } \\
\text { być kontrolowane. } \\
\text { Gracze najbardziej zagrożeni } \\
\text { konfliktem interesów muszą } \\
\text { być świadomi ich etycznej } \\
\text { odpowiedzialności za działania } \\
\text { ukierunkowane na ich partnerów }\end{array}$ \\
\hline
\end{tabular}

Źródło: opracowanie własne na podstawie Dembinski, 2012.

Ze względu na rolę spełnianą w systemie norm moralnych przez normy strzegące sprawiedliwości, analizując w artykule zachowania przedsiębiorstw i identyfikując ich zachowania nietyczne, poszukuje się zachowań, które są niezgodne z normą sprawiedliwości.

W literaturze przedmiotu wyróżnia się dwa podstawowe rodzaje sprawiedliwości: dystrybutywną i proceduralną. Sprawiedliwość dystrybutywna (nazywana też rozdzielczą) oznacza społeczny i sprawiedliwy podział towarów. Możne być utożsamiana ze sprawiedliwą alokacją dóbr. Sprawiedliwość dystrybutywna koncentruje się na wynikach. Uważa się, że społeczeństwo, w którym powstają nierówności, nie może być uważane za społeczeństwo kierujące się zasadami sprawiedliwości dystrybutywnej. Podobnie relacje, w trakcie których powstają nierówności między uczestnikami, nie mogą być uznane za ukształtowane na zasadach sprawiedliwości dystrybutywnej. Kumar Nirmalya (1996) stwierdził, że sprawiedliwość dystrybutywna 
dotyczy nie tylko tego, jak między partnerami powinny być dzielone korzyści, ale i obowiązki. W tym kontekście zwrócił uwagę, iż istnieją przedsiębiorstwa, które dążą tylko do maksymalizacji korzyści uzyskiwanych przez siebie, podczas gdy inne dostrzegają, że ponoszą odpowiedzialność także za zyskowność swoich partnerów. Wspomniane podejścia etyka biznesu i etyka w biznesie wyjaśniają przyczyny zróżnicowania tych dążeń.

Sprawiedliwość dystrybutywna ma charakter rezultatowy, ponieważ jest rezultatem określonego sposobu podziału, natomiast w sprawiedliwości proceduralnej można dostrzec aspekt czynnościowy, gdyż odnosi się do czynności podejmowanych w trakcie podziału i ich cech. Nirmalya (1996) uważa, że ma ona silniejszy wpływ na relacje między stronami niż ten, jaki wywiera sprawiedliwość dystrybutywna.

Sprawiedliwość proceduralna dotyczy uczciwości procesów czy procedur stosowanych przez strony podziału $\mathrm{w}$ celu radzenia sobie $\mathrm{z}$ ich wrażliwymi partnerami. Istota proceduralnego podejścia do sprawiedliwości polega na zapewnieniu bezstronnego i konsekwentnego stosowania obowiązujących norm. W szczególności wyraża się w traktowaniu każdego podmiotu zgodnie $\mathrm{z}$ formalnie przyjętymi regułami proceduralnymi. Ważne jest założenie, że decyzja o podziale ma być podejmowana w sposób zinstytucjonalizowany, tj. przez podmioty do tego powołane i działające na bazie określonego prawidła proceduralnego (Bernatt, 2011, s. 34). Grzegorz Lissowski (2008) uważa, że procedurę podziału dóbr można uznać za sprawiedliwą, jeśli ma pewne pożądane właściwości i pozwala każdemu uczestnikowi podziału osiągnąć dzięki niemu zadowalający poziom satysfakcji. Takie cechy może mieć rozwiązanie lub procedura, która do niego prowadzi. W przypadku procedury występowanie tych właściwości stwierdza się na podstawie porównania rozwiązań dla różnych profili użyteczności uczestników podziału, w przypadku rozwiązania na podstawie własności wyznaczonego rozwiązania (Lissowski, 2008, s. 348-349).

Nowo wygenerowana wartość jest jedną z postaci pożytku, jaki powstaje w toku relacji między przedsiębiorstwami. Jest ona dzielona pomiędzy tych, którzy ją wytworzyli. Zatem musi być podjęte rozstrzygnięcie, co do tego, w jakiej proporcji będzie im przydzielona. Oznacza to, że do procesu alokacji wartości odnosi się kategoria sprawiedliwości dystrybutywnej. Fundamentalne kryterium sprawiedliwości dystrybutywnej wskazała Sternberg. Stwierdziła, iż w najbardziej ogólnym ujęciu zasada ta oznacza, że w organizacji gratyfikacje powinny [podkr. - B.G.] być dzielone proporcjonalne do wkładu wniesionego w osiągnięcie jej celów. Sprawiedliwość dystrybutywna ma stanowić (Sternberg, 1998, s. 99 i nn.):

(a) uzasadnienie przyznawania korzyści - jest nim wnoszenie wkładów w osiąganie celów współdziałających podmiotów,

(b) kryterium dokonywania podziału osiągniętych korzyści - jest nim proporcjonalność wartości wniesionych wkładów w osiąganie wspólnych celów. 
Odmienne od powyższych stosowane w praktyce [podkr. - B.G.] reguły alokacji wskazał Hobart Peyton Young. Zwykle odwołują się one do jednej z poniższych koncepcji sprawiedliwości (Young, 2003, s. 170):

(a) równouprawnienie - oznacza, że pretendenci mają być traktowani równo, ponieważ:

- rzeczywiście są równi,

- nie ma jasnych kryteriów pozwalających dokonać rozróżnienia między nimi,

(b) priorytet - nakazuje, by określone dobro otrzymał podmiot mający do tego największe prawo,

(c) proporcjonalność - uznaje się różnice pomiędzy pretendentami i dzieli się określone dobro w proporcji do tych różnic.

Sprawiedliwość dystrybutywna dotyczy przede wszystkim osiągnięć. Służy zarówno jako zasada podziału, jak i zasada wyboru. Dla wydania osądu z punktu widzenia sprawiedliwości dystrybutywnej ważny jest sam wkład konkretnego podmiotu. Zdolności czy aspiracje są istotne o tyle, o ile rzeczywiście wpływają na wygenerowaną wartość (Sternberg, 1998, s. 100-101). W artykule zastosowano rozszerzającą wykładnię pojęcia "sprawiedliwość dystrybutywna”, odnosząc ją także do rezultatów relacji między przedsiębiorstwami.

Wymienione przez Sternberg (1998, s. 99-101) zachowania niezalecane z punktu widzenia sprawiedliwości dystrybutywnej pozwalają a contrario określić zalecane z punktu widzenia tego kryterium zachowania w relacjach między przedsiębiorstwami:

(1) Odnieść się do wkładów każdej ze stron mających wpływ na wielkość wartości wygenerowanej w trakcie określonej relacji.

(2) Wykorzystać przypisany przez oceniającego cel relacji, zwykle generowanie i zatrzymanie wartości, chyba że z obserwacji (lub innych przesłanek) wynika, iż ten cel ma bardziej specyficzny charakter, np. zdobycie nowych kompetencji czy wiedzy.

(3) Sprawiedliwość dystrybutywną rozpatrywać tylko w ramach konkretnej relacji.

(4) Przy podziale wartości nie traktować jednakowo współdziałających podmiotów. Odwrotnie: podmiot wnoszący większy wkład w wygenerowanie wartości winien otrzymać większy udział.

Za kluczowe kryterium oceny podziału z punktu widzenia zgodności z zasadami sprawiedliwości dystrybutywnej, za Sternberg, należy uznać proporcjonalność, tym bardziej że Young również wskazał je jako stosowane w praktyce. Oznacza to, iż gratyfikacje są dzielone stosownie do wkładu wniesionego w osiągnięcie celów. To kryterium może być wykorzystane do oceny rzeczywistych relacji jako 
sprawiedliwych albo niesprawiedliwych dystrybutywnie. Odnosząc ten pogląd do podziału wartości między przedsiębiorstwami, należy przyjąć, że z uwagi na to, iż każdy z podmiotów wnosi do generowania wartości wkład w określonej proporcji do całości wkładów, powinien w takiej samej proporcji uczestniczyć w podziale wygenerowanej wartości. Wydaje się, że w przypadku podziału wartości między przedsiębiorstwami do oceny sprawiedliwości dystrybutywnej można przyjąć następującą formułę (Gulski, 2017, s. 132):

$$
\mathrm{V}_{\mathrm{A}} / \mathrm{V}_{\mathrm{B}}=\Sigma \mathrm{Z}_{\mathrm{A}} \mathrm{xW}_{\mathrm{A}} / \Sigma \mathrm{Z}_{\mathrm{B}} \mathrm{x} \mathrm{W}_{\mathrm{B},}
$$

gdzie:

$\mathrm{V}_{\mathrm{A}}, \mathrm{V}_{\mathrm{B}}$ - wielkość wartości otrzymanej przez przedsiębiorstwo $\mathrm{A}$ lub $\mathrm{B}$,

$Z_{A}, Z_{B}-$ ocena wielkości zasobów zaangażowanych przez przedsiębiorstwo A lub B w wygenerowanie wartości,

$\mathrm{W}_{\mathrm{A}}, \mathrm{W}_{\mathrm{B}}$ - ocena cenności zasobów przedsiębiorstwa A lub B z punktu widzenia przyczynienia się do wygenerowania wartości.

Spełnienie warunku zawartego w powyższej formule oznacza, że podział wartości wygenerowanej przez współdziałające przedsiębiorstwa jest zgodny z zasadami sprawiedliwości dystrybutywnej, tzn. wartość podzielono proporcjonalnie do wkładu w jej wygenerowanie. W innych przypadkach można sądzić, że nie występuje sprawiedliwość dystrybutywna.

Sprawiedliwość podziału dóbr jest uzależniona od różnych czynników, m.in. od charakteru dystrybuowanego dobra, istotnych cech pretendentów, ich przekonań i podzielanych wartości, precedensów określających, jakie działanie w sytuacji określonego typu jest normalne, zwyczajowe czy oczekiwane. Pojęcie sprawiedliwości, zdaniem Younga, nie jest arbitralne i nie istnieje tylko w umyśle dokonującego konkretnej oceny (Young, 2003, s. 231), dlatego opinie formułowane w przedsiębiorstwach o podziale wartości mogą powodować konkretne, realne skutki. Te skutki mogą być niezwykle istotne z punktu widzenia realizacji CZR i wynikających z nich zadań.

\section{Podstawy generowania i podziału wartości przez przedsiębiorstwa}

Podejmowane przez duże przedsiębiorstwa decyzje odnoszące się do alokacji zasobów wywierają wielki wpływ na osiągnięcia całej gospodarki: (a) bezpośrednio w odniesieniu do wyrobów i usług wytwarzanych przez te przedsiębiorstwa oraz do ludzi, których zatrudniają, (b) pośrednio, ponieważ dochody milionów mniejszych przedsiębiorstw zależą od sprzedaży wyrobów i usług dużym podmiotom i ich 
pracownikom (Lazonick, 2017). Dlatego tak ważny jest sposób podziału współgenerowanej wartości.

$\mathrm{W}$ trakcie relacji między przedsiębiorstwami podejmowane są zróżnicowane zachowania. Niektóre z nich, nieetyczne, mogą zagrażać realizacji CZR. Wspomniane zagrożenia $\mathrm{w}$ dużym stopniu wynikają $\mathrm{z}$ istoty przebiegu procesów generowania, podziału i zatrzymywania wartości przez przedsiębiorstwa. Stopień złożoności produktów wytwarzanych przez współczesne przedsiębiorstwa powoduje, że ich samodzielne produkowanie jest $\mathrm{z}$ reguły bardzo utrudnione. Stąd dominuje tzw. kooperatywne generowanie wartości (Gulski, 2017, s. 73 i nn.) polegające najogólniej na tym, że przedsiębiorstwa łączą swoje zasoby (materialne i niematerialne) po to, by wyprodukować i sprzedać produkty, a następnie dokonać podziału uzyskanej od nabywców wartości wymiennej. Tak opisany proces ma wiele odmian i wariantów różniących się między sobą m.in. charakterem wkładu przedsiębiorstw w generowanie wartości, momentem, w którym następuje podział wartości wymiennej, wielkością ryzyka finansowego ponoszonego przez przedsiębiorstwa uczestniczące w generowaniu wartości.

Zaprezentowane w tabeli 2 wybrane cele i zadania zrównoważonego rozwoju $\mathrm{z}$ reguły są ukierunkowane na poprawę sytuacji małych i średnich przedsiębiorstw. Zaangażowanie dużych, a przynajmniej silniejszych pod jakimś względem (np. ilości i nowoczesności posiadanych zasobów) przedsiębiorstw ułatwia, a czasem umożliwia ich osiągnięcie. Współudział tych przedsiębiorstw może przybierać różne postaci, ale możliwe jest wskazanie dwóch typowych przypadków. Na rysunkach 1 i $2 \mathrm{w}$ postaci modeli przedstawiono takie sytuacje. Jako swego rodzaju uogólnienia zostaną one wykorzystane do wyjaśnienia mechanizmów mogących wywołać zagrożenie dla realizacji wybranych CZR i zadań służących ich osiągnięciu.

Pierwszy z modeli ilustruje sytuację, w której przedsiębiorstwo uzyskuje możliwość korzystania z zasobów innego podmiotu (w postaci świadczonej usługi), uiszczając za to należność. Tę opłatę można uznać za udział w wartości wymiennej otrzymanej przez przedsiębiorstwo korzystające z zasobów, która trafiła do przedsiębiorstwa udostępniającego zasoby. Drugi z rysunków obrazuje przypadek, w którym przedsiębiorstwo, mając techniczne możliwości prowadzenia pewnego rodzaju działalności, zleca go innemu podmiotowi, od którego oczekuje tańszego wykonawstwa.

Zgodnie z założeniami teorii zasobowej przedsiębiorstwo może być rozpatrywane jako zestaw zasobów, które - odpowiednio zorganizowane i wykorzystane generują wartość dla nabywców. Gdy przedsiębiorstwo ze względu na brak zasobów (na rysunku 1 przedsiębiorstwo A) nie może produkować określonych wyrobów i/lub świadczyć usług, wówczas mówimy o luce zasobowej. Jednak deficyt zasobów ma charakter względny - może dotyczyć tylko niektórych produktów. Deficyt pojawia się w szczególności w przypadku zamiaru wprowadzenia innowacji, np. 
rozpoczęcia nowego rodzaju działalności czy dokonania daleko idących modyfikacji w dotychczasowej aktywności. Przedsiębiorstwo może pokonać deficyt samodzielnie, wytwarzając lub nabywając potrzebne zasoby. Jednak w pierwszym przypadku jest to długotrwałe, a w drugim kosztowne. Alternatywą jest wykorzystanie zasobów należących do innego przedsiębiorstwa (na rysunku 1 przedsiębiorstwo B). Może ono polegać na wydzierżawieniu tychże zasobów od innych podmiotów lub zleceniu innym podmiotom wykonanie operacji wymagających deficy towych zasobów. Za wydzierżawione zasoby lub wykonaną usługę uiszczana jest należność, która w istocie stanowi udział w wartości wymiennej otrzymanej przez przedsiębiorstwo, które odczuwało deficyt zasobów.

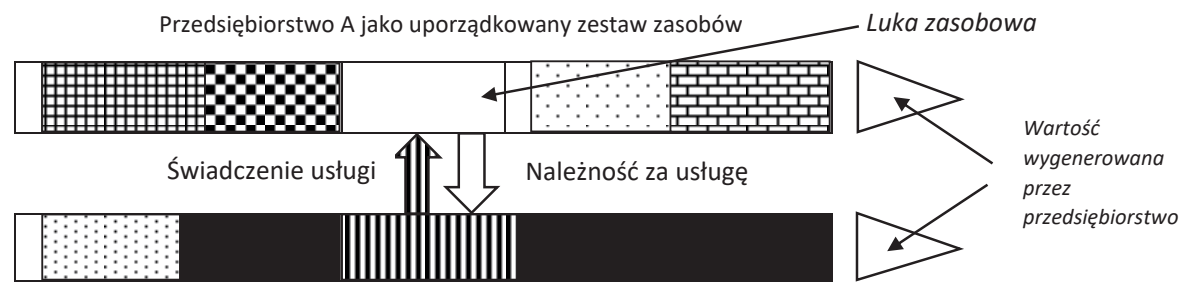

Przedsiębiorstwo B jako uporządkowany zestaw zasobów

Rysunek 1. Zasoby przedsiębiorstwa jako czynnik umożliwiający generowanie wartości przez przedsiębiorstwo

Źródło: opracowanie własne.

Na rysunku 2 przestawiono model sytuacji, w której przedsiębiorstwo C rezygnuje z prowadzenia pewnego rodzaju działalności, mimo że dysponuje odpowiednimi zasobami (materialnymi lub niematerialnymi). Przedsiębiorstwo C, zlecając odpłatną realizację operacji wykonywanych w określonym ogniwie łańcucha wartości, powinno zapewnić sobie kontrolę nad przestrzeganiem przez przedsiębiorstwo D swoich standardów. Motywem takiego zachowania przedsiębiorstwa jest $\mathrm{z}$ reguły stosunkowo mała wartość generowana w określonym ogniwie. Może to wynikać z niskiej wagi przypisywanej przez klientów efektom uzyskiwanym w takim ogniwie łańcucha wartości, a tym samym niskiej skłonności do opłacenia wysiłków przedsiębiorstwa, np. w branży odzieżowej proste szycie jest źródłem przede wszystkim wartości użytkowej (np. ochrony przed chłodem), którą niektórzy klienci stawiają znacznie niżej niż wartość emocjonalną (wyróżniające wzornictwo, prestiżowa marka). Z punktu widzenia przedsiębiorstwa podejmującego się realizacji określonej aktywności (na rysunku 2 przedsiębiorstwo D) jest to okazja do 
pełniejszego wykorzystania posiadanych zdolności produkcyjnych albo ich rozwoju, by dać zatrudnienie większemu gronu pracowników (zostanie o tym wspomniane przy okazji opisu realizacji zadania 9.3). Podział wartości, którą wygenerowano w łańcuchu wartości przedsiębiorstwa C, zachodzi w trakcie ustalania wynagrodzenia przedsiębiorstwa D za włączenie się w łańcuch.

Łańcuch wartości przedsiębiorstwa C rezygnującego z aktywności

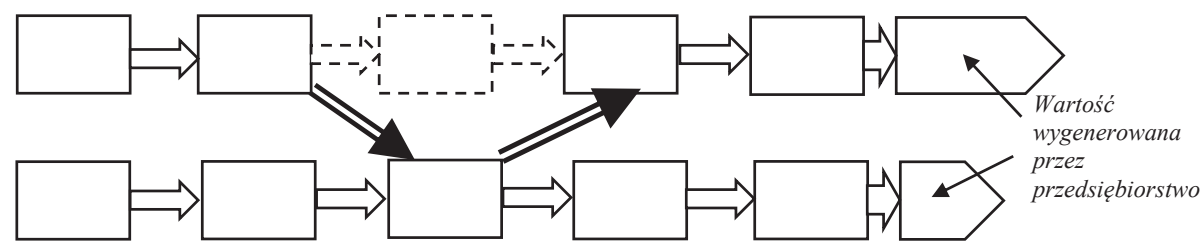

Łańcuch wartości przedsiębiorstwa D podejmującego aktywność

Rysunek. 2. Łańcuchy wartości przedsiębiorstwa rezygnującego z aktywności w wybranym ogniwie łańcucha wartości i przedsiębiorstwa podejmującego tę samą aktywność

Źródło: opracowanie własne.

W sytuacji przedstawionej na rysunku 1 uzyskanie dostępu do zasobów warunkuje generowanie wartości przez przedsiębiorstwo A - bez nich nie mogłoby prowadzić jednego $\mathrm{z}$ rodzajów działalności i generować wartości. $\mathrm{W}$ innej sytuacji jest przedsiębiorstwo $\mathrm{D}$, które bez uzyskania zlecenia od przedsiębiorstwa $\mathrm{C}$ mogłoby generować wartość, prowadząc dotychczasowe aktywności, ale całkowita wartość wygenerowana byłaby mniejsza. W obu przypadkach dochodzi do uzależnienia przedsiębiorstwa od jego partnera, co stanowi konsekwencję braku możliwości samodzielnego generowania wartości w pożądanych rozmiarach. Istota tego uzależnienia polega na konieczności podporządkowania, choćby w części, swoich interesów wymogom podmiotów umożliwiających wygenerowanie wartości w większych rozmiarach. Takie uzależnienie przedsiębiorstwa prowadzi do ograniczenia jego autonomii decyzyjnej, uniemożliwiającej podejmowanie decyzji optymalnych, $\mathrm{np}$. akceptacji warunków, na jakich są nawiązywane relacje $\mathrm{z}$ innymi przedsiębiorstwami, nawet jeżeli są one niekorzystne $\mathrm{z}$ ich punktu widzenia. Znaczenie tak rozumianej zależności jest zbliżone do rozumienia przemocy przedstawionego w opisie zadania 16.1 . 


\section{Wybrane Cele Zrównoważonego Rozwoju i zadania angażujące przedsiębiorstwa}

Ze względu na przedmiot rozważań prowadzonych w artykule, którymi są relacje między przedsiębiorstwami, poniżej skoncentrowano się tylko na niektórych CZR oraz wynikających z nich zadaniach. Dokonany dobór celów i zadań jest konsekwencją zamiaru autora, by skupić się na tych z nich, których realizacja wymaga zaangażowania różnych przedsiębiorstw (choć jest rzeczą oczywistą, że zaangażowanie innych podmiotów, np. rządów, władz lokalnych, fundacji, jest również pożądane). Współdziałające przedsiębiorstwa nawiązują relacje, w trakcie których są podejmowane zróżnicowane zachowania, co stwarza przestrzeń do etycznej refleksji nad relacjami i zachowaniami w ich trakcie. W tabeli 2 przedstawiono wspomniane cele i zadania.

Tabela 2. Wybrane Cele Zrównoważonego Rozwoju i zadania, które implikują zagrożenia etyczne w relacjach między przedsiębiorstwami

\begin{tabular}{|c|c|c|}
\hline Lp. & Wybrane Cele Zrównoważonego Rozwoju & Wybrane zadania związane $\mathrm{z}$ celem \\
\hline \multirow[t]{2}{*}{1.} & $\begin{array}{l}\text { Cel 8: } \\
\text { Wzrost gospodarczy i godna praca }\end{array}$ & $\begin{array}{l}\text { 8.2. Osiągnąć wyższy poziom wydajności gospo- } \\
\text { darczej przez dywersyfikację, moderniza- } \\
\text { cję technologiczną i innowacje, a także przez } \\
\text { skupienie się na sektorach o wysokiej warto- } \\
\text { ści dodanej oraz o wysokim wskaźniku praco- } \\
\text { chłonności. }\end{array}$ \\
\hline & & $\begin{array}{l}\text { 8.3. Promować polityki rozwojowe wspierające } \\
\text { działalność produkcyjną, tworzenie godziwych } \\
\text { miejsc pracy, przedsiębiorczość, kreatywność } \\
\text { i innowacje. Zachęcać do formalizacji i rozwoju } \\
\text { mikro, małych i średnich przedsiębiorstw, w tym } \\
\text { poprzez dostęp do usług finansowych }\end{array}$ \\
\hline 2. & $\begin{array}{c}\text { Cel 9: } \\
\text { Innowacyjność, przemysł, infrastruktura }\end{array}$ & $\begin{array}{l}\text { 9.3. Zwiększyć dostęp małych i innych przedsię- } \\
\text { biorstw, w tym przemysłowych, w szczególności } \\
\text { w krajach rozwijających się, do usług finansowych } \\
\text { i przystępnych kredytów oraz włączyć je w łańcu- } \\
\text { chy wartości i zapewnić udział w rynku }\end{array}$ \\
\hline 3. & $\begin{array}{l}\text { Cel 10: } \\
\text { Mniej nierówności }\end{array}$ & $\begin{array}{l}\text { 10.3. Zapewnić równe szanse oraz zmniejszać ist- } \\
\text { niejące nierówności poprzez eliminowanie dys- } \\
\text { kryminujących praw, polityk i praktyk oraz } \\
\text { promować odpowiednią legislację, polityki i dzia- } \\
\text { łania w tej dziedzinie }\end{array}$ \\
\hline 4. & $\begin{array}{l}\text { Cel 12: } \\
\text { Odpowiedzialna konsumpcja i produkcja }\end{array}$ & $\begin{array}{l}\text { 12.6. Zachęcać przedsiębiorstwa, w szczególności } \\
\text { te duże i międzynarodowe, do wdrażania praktyk } \\
\text { w zakresie zrównoważonego rozwoju i uwzględ- } \\
\text { niania informacji na ten temat w swoich cyklicz- } \\
\text { nych raportach }\end{array}$ \\
\hline
\end{tabular}




\begin{tabular}{ccc}
\hline Lp. & Wybrane Cele Zrównoważonego Rozwoju & Wybrane zadania związane z celem \\
\hline 5. & Cel 16: & $\begin{array}{l}\text { 16.1. Znacząco zmniejszyć poziom przemocy we } \\
\text { wszystkich formach oraz związany z nią wskaźnik } \\
\text { śmiertelności na całym świecie }\end{array}$ \\
\hline
\end{tabular}

Źródło: opracowanie własne na podstawie danych United Nations Global Compact. Pobrane z: ungc. org.pl/sdg/sustainable-develompent-goals (15.05.2019).

Charakterystyka wyróżnionych w tabeli 2 zadań ma umożliwić późniejszą identyfikację ewentualnych zachowań nieetycznych związanych $\mathrm{z}$ ich realizacją.

Za da ni e 8.2. Mariana Mazzucato (2021, s. 224), uważana za jedną z najważniejszych intelektualistek w dziedzinie ekonomii innowacji, postawiła tezę, że najnowocześniejsza forma przechwytywania renty w XXI-wiecznej gospodarce bazującej na wiedzy ma postać uspołeczniania ryzyka i prywatyzacji zysków generowanych przez innowacje. Ta opinia jest istotna ze względu na to, że wskazane w zadaniu 8.2 kierunki aktywności to w istocie zróżnicowane postaci innowacji, które miałyby wdrażać małe przedsiębiorstwa. Oznacza to, że oczekuje się, iż takie przedsiębiorstwa będą dokonywać innowacji, które w szczególności miałyby spowodować dywersyfikację (np. produktową), modernizację technologiczną (np. innowacje w sposobach wytwarzania wyrobów czy świadczenia usług). Podobnie koncentracja na sektorach o wysokiej wartości dodanej może być konsekwencją umiejętnych innowacji skutkujących „wejściem” do bardziej wartościotwórczych sektorów albo dokonania innowacji technologicznych, dzięki którym przedsiębiorstwo będzie generować wartość o większych rozmiarach lub nowe wartości dla klientów.

Koncentracja na sektorach o wysokiej pracochłonności winna być traktowana nie tyle jako sposób na zapewnienie rozwoju przedsiębiorstwa, ale raczej narzędzie realizacji celów społecznych, w szczególności ograniczenia bezrobocia.

Pokonanie przez małe czy średnie przedsiębiorstwa ograniczeń w implementacji innowacji związanych z ryzykiem czy kosztami jest ułatwione przez współdziałanie z dużymi przedsiębiorstwami. Na zależność od podmiotów zewnętrznych, w sytuacji gdy przedsiębiorstwo potrzebuje kluczowych zasobów, zwrócili uwagę Lourdes Pérez i Jesús J. Cambra Fierro (2018), którzy taką sytuację rozpatrywali w odniesieniu do startupów technologicznych. Inny aspekt tego zjawiska dostrzegła Mazzucato (2021, s. 227), twierdząc, że proces tworzenia innowacji cechuje się wspólnotowością - jego istotową częścią są interakcje między różnymi ludźmi, odgrywającymi różne role i reprezentującymi różne sektory. Wydaje się uzasadnione rozszerzenie tego poglądu na przedsiębiorstwa, od których również można oczekiwać specyficznej wspólnotowości. 
Jednak podejmowanie współdziałania z dużymi podmiotami jest obarczone ryzykiem. Mikro, małe, a nawet średnie przedsiębiorstwa w sektorach o wysokiej wartości dodanej z reguły mogą pracować na zlecenie większych przedsiębiorstw i być jedynie dostawcą (np. mniej wartościowych usług). Większe przedsiębiorstwa mogą również, wykorzystując asymetrię informacyjną, unikać udostępniania współdziałającym mniejszym przedsiębiorstwom względnie nowych technologii, oczekując świadczeń takich jak za najnowsze. Możliwe jest również stosowanie trollingu patentowego i wykorzystywanie go jako dodatkowego źródła dochodów większych przedsiębiorstw. W konsekwencji wymienionych zachowań większe podmioty mogą uzyskiwać korzyści nieproporcjonalnie duże do poniesionych nakładów, a przy tym nie zapewniać rozwoju małych podmiotów, czyli zachowywać się nieetycznie.

$\mathrm{Z}$ a d a n ie 8.3. Współcześnie działalność produkcyjna generuje mniej wartości niż świadczenie usług, szczególnie zaawansowanych usług profesjonalnych. Dlatego jedną z form włączania się dużych przedsiębiorstw w realizację zadania 8.3 jest zlecanie do wykonania zadań i operacji wykorzystujących zasoby mikro, małych i czasami średnich przedsiębiorstw. Jednak ze względu na ograniczenia zasobowe ich współpraca z dużymi przedsiębiorstwami zwykle ogranicza się do realizacji względnie prostych operacji, generujących niewiele wartości. Mniejsze przedsiębiorstwa mogą spełniać funkcję dostawców komponentów dla dużych przedsiębiorstw, gdy samodzielnie nie są $\mathrm{w}$ stanie zaoferować atrakcyjnych produktów końcowym odbiorcom. W ten sposób duże przedsiębiorstwa stają się specyficznymi kanałami dystrybucji małych podmiotów, umożliwiając im dotarcie do takich klientów, do których samodzielnie by nie dotarły. Tego rodzaju współdziałanie z dużymi podmiotami może ułatwić tworzenie atrakcyjnych miejsc pracy oraz podejmowanie w nich nowych przedsięwzięć. Jednakże wskutek wskazanych form współpracy może powstać grupa przedsiębiorstw uzależnionych od większych podmiotów, mających względnie słabą pozycję negocjacyjną w stosunku do nich. W konsekwencji podział wygenerowanej wspólnie wartości jest nieproporcjonalny. Uzależnienie i słabość negocjacyjna mniejszych podmiotów wynika z niektórych ich specyficznych cech, w szczególności ograniczonej ilości zasobów, którymi dysponują.

$\mathrm{Zad}$ an i e 9.3. Kluczowe znaczenie dla realizacji tego zadania ma włączenie się państw, stwarzających odpowiednie warunki, oraz - w sposób bardziej bezpośredni - przedsiębiorstw, w szczególności współdziałających z mniejszymi podmiotami, włączając je w swoje łańcuchy. Tworzenie łańcuchów wartości przez mniejsze przedsiębiorstwa może zachodzić $\mathrm{w}$ ramach (a) jednorazowych porozumień między nimi, (b) zawierania trwalszych aliansów. Warto zwrócić uwagę na możliwość kooperencji między małymi przedsiębiorstwami. Włączanie małych przedsiębiorstw w łańcuchy wartości dużych podmiotów przynosi korzyści w postaci: uzyskania zleceń, większych obrotów, większego zaufania klientów, dostępu do globalnych 
klientów, długookresowego rozwoju przedsiębiorstwa, dostępu do wiedzy i technologii, usprawnienia zarządzania, łatwiejszego konkurowania (przedsiębiorstwo konkuruje jako uczestnik sieci), optymalizowania wielkości produkcji, ograniczonych kosztów transakcyjnych, łatwiejszego poszukiwania nowych kontrahentów (V. K. Fung, W. K. Fung, Y. (J.) Wind, 2008, s. 148-149). Udział w łańcuchu wartości dużego przedsiębiorstwa stwarza mniejszym podmiotom warunki do specjalizacji i rozwoju zasobów, ale ukierunkowanego na zaspokojenie potrzeb dużego. Jednak uczestnictwo w łańcuchu wartości dużego przedsiębiorstwa często wymaga przyjęcia jego standardów, zajęcia wskazanego miejsca w łańcuchu wartości czy ograniczenia możliwości realizacji własnych aspiracji rozwojowych, co w istocie stanowi formę uzależnienia od dużego podmiotu i wywołuje zagrożenie niesprawiedliwym podziałem wartości.

$\mathrm{Z}$ ad an i e 10.3. Skuteczna realizacja tego zadania jest uzależniona od zaangażowania państw, które, uchwalając konieczne regulacje, tworzą warunki do eliminowania dyskryminacji. Natomiast przedsiębiorstwa, kierując się zasadami etyki w biznesie (Dembinski, 2012) oraz przestrzegając wspomnianych regulacji w relacjach z innymi podmiotami, również realizują to zadanie. Eliminacja dyskryminujących praktyk winna dotyczyć nie tylko pojedynczych osób, ale także podmiotów gospodarczych, w szczególności mniejszych. Ze względu na przedmiot rozważań należy zwrócić uwagę na zagrożenie stosowaniem wobec mniejszych przedsiębiorstw praktyk określanych jako przemoc symboliczna, którą Pierre Bourdieu (2008, s. 172) opisał następująco:

To przemoc delikatna, niewidoczna, nierozpoznana jako przemoc, zarówno wybrana, jak i doświadczana, przemoc zaufania, zobowiązania, osobistej wierności, gościnności, daru, długu, uznania, nabożności - słowem wszystkich cnót, jakie uznaje moralność honoru, nasuwa się zatem jako sposób dominacji najekonomiczniejszy, jako że w największym stopniu zgodny z ekonomią systemu.

Jakkolwiek z formalno-prawnego punktu widzenia nie są one zakazane, mogą być wykorzystane do wywierania wpływu na mniejsze podmioty, co może skutkować niesprawiedliwym podziałem wartości.

Zad a n ie 12.6. Spośród wielu zjawisk, z którymi związana jest realizacja tego zadania, należy zwrócić uwagę na potrzebę kształtowania przez duże przedsiębiorstwa równorzędnych relacji z mniejszymi podmiotami, które ze swej natury są narażone na zachowania zmierzające do ich zdominowania (o czym wspomniano, komentując zadanie 10.3). W szczególności ważne jest unikanie stwarzania asymetrii informacyjnej w relacjach $\mathrm{z}$ otoczeniem i mniejszymi podmiotami, stosowania phishingu wobec osób indywidualnych, value extraction wobec podmiotów gospodarczych. 
Zadanie 16.1. Analiza tego zadania została ograniczona do zmniejszenia przemocy, jaką wobec mniejszych organizacji mogą stosować duże przedsiębiorstwa, które nawiązały z nimi relacje. Przemoc stosowaną w tego rodzaju sytuacjach można określić jako takie oddziaływanie na przedsiębiorstwo, które powoduje, że rzeczywisty poziom jego osiągnięć jest niższy niż możliwy - z dużym prawdopodobieństwem - do osiągnięcia. Spośród wielu rodzajów przemocy szczególną uwagę należy zwrócić na przemoc ukrytą, gdy podmiot, wobec którego jest stosowana, nie jest jej świadom, choć może odczuwać jej skutki, oraz przemoc symboliczną. Zastosowanie wspomnianych rodzajów przemocy wobec małych przedsiębiorstw może powodować, że w sposób nieuświadomiony poddają się praktykom, które z obiektywnego punktu widzenia są dla nich niekorzystne.

W realizacji CZR, zdaniem United Nations Global Compact, jak i całej ONZ, sektor prywatny pełni kluczową rolę. Jego wpływ na osiągnięcie CZR rozpatruje się w czterech blokach ${ }^{3}$. Ze względu na cele prowadzonych rozważań szczególną uwagę zwrócono na działania ujęte w następujących blokach: „Rozwój” (blok I) oraz „Środowisko sprzyjające rozwojowi człowieka” (blok IV). Analiza działań ujętych w obu blokach pozwala stwierdzić, że także w trakcie ich realizacji mogą wystąpić sytuacje, w których możliwe jest pojawienie się zachowań nieetycznych mogących zagrozić realizacji CZR.

Wśród zadań określonych w bloku I sy tuacją grożącą zachowaniami nieetycznymi jest podział wartości wygenerowanej podczas współdziałania mniejszych przedsiębiorstw z dużymi. Sprawiedliwość podziału takiej wartości pozwala uniknąć tworzenia przedsiębiorstw, które są pozbawione perspektyw rozwoju, oferujących stanowiska pracy z głodowymi wynagrodzeniami. Natomiast niesprawiedliwy podział wartości skutkuje brakiem osiągnięcia niektórych efektów ujętych w bloku „Rozwój”. W obrębie bloku I rozpatruje się również zjawiska występujące w łańcuchach wartości. Jakkolwiek niektóre z praktyk mających miejsce w tych łańcuchach nie są nielegalne (mogą polegać np. na stosowaniu przemocy symbolicznej wobec małych przedsiębiorstw), to prowadzą do naruszenia zasad sprawiedliwości proceduralnej i dystrybutywnej w trakcie relacji między przedsiębiorstwami, skutkującymi niesprawiedliwym podziałem wartości.

W związku z omawianym blokiem również zwraca się uwagę na wsparcie ze strony dużych przedsiębiorstw, ułatwiające małym organizacjom rozwój i późniejszą ekspansję, wyrażające się m.in. zwiększaniem obrotów i liczby zatrudnionych. Jednak ze względu na to, że duże przedsiębiorstwa zwykle funkcjonują w formie spółek handlowych, a często także spółek publicznych, mają one formalne zobowiązania w stosunku do swoich udziałowców, zaś naruszenie ich interesów może spowodować zarzuty, a nawet postępowania karne w stosunku do zarządów spółek.

3 Pobrane z: ungc.org.pl/sdg/sustainable-develompent-goals/ (15.05.2019). 
Wynika stąd, że wspieranie małych przedsiębiorstw przez duże może przybierać tylko określone formy, czyli takie, które nie powodują negatywnych skutków dla dużych przedsiębiorstw.

W bloku „Środowisko sprzyjające rozwojowi człowieka” za ważny z punktu widzenia celów artykułu uznano punkt „Dobre Rządzenie i Prawa Człowieka”. Realizacja CZR przez przedsiębiorstwa - w kontekście omawianego punktu - polega przede wszystkim na tym, by w trakcie funkcjonowania przestrzegać przepisów. Należy w szczególności zwrócić uwagę na przepisy regulujące sytuację pracowników przedsiębiorstwa, w tym standardy pracy i wynagradzania oraz odnoszące się do mobbingu. W relacjach $\mathrm{z}$ odbiorcami winno się podkreślić przestrzeganie przepisów regulujących prawa konsumentów, ale także unikanie praktyk, które jakkolwiek nie naruszają przepisów, ale są niekorzystne dla nabywców m.in. zaliczanych do tzw. phishingu. Natomiast $\mathrm{w}$ relacjach $\mathrm{z}$ innymi przedsiębiorstwami należy podkreślić ważność przepisów antymonopolowych i odnoszących się do nieuczciwej konkurencji.

Realizacja niektórych z celów i zadań zrównoważonego rozwoju jest uzależniona od nawiązania relacji między dużymi a mniejszymi przedsiębiorstwami. Jednak nawiązanie relacji między przedsiębiorstwami dwojako wpływa na sytuację uczestników relacji. Z jednej strony stwarza warunki do realizacji CZR, ale z drugiej niektórym przedsiębiorstwom może stwarzać zachętę do podejmowania zachowań, które służą tylko realizacji ich własnych aspiracji ze szkodą dla innych uczestników relacji i osiągnięcia CZR. Jednak samo nawiązanie tych relacji jest niewystarczające z punktu widzenia realizacji omawianych celów.

\section{Zachowania nieetyczne przedsiębiorstw}

Poszukując zbioru potencjalnych zachowań nieetycznych przedsiębiorstw, które mogą negatywnie wpływać na realizację CZR i zadań służących ich urzeczywistnieniu, zastosowano dwa podejścia. W pierwszym przeprowadzono analizę i ocenę zachowań przedsiębiorstw uwzględniającą ich nastawienia na kluczowe wartości, i badano, w jaki sposób w zachowaniach przedsiębiorstw wyrażają się takie nastawienia. Nastawienia przedsiębiorstw zostały tu potraktowane jako endogeniczny czynnik kształtujący ich zachowania. W drugim podejściu identyfikowano zachowania przedsiębiorstw podejmowane w wybranych obszarach konfliktu współczesnych przedsiębiorstw, które negatywnie wpływają na realizację celów i zadań zrównoważonego rozwoju. Zakres analizowanych zachowań został w tym podejściu ograniczony w ten sposób, że analizowano tylko te z nich, które mogły być konsekwencją stosowania przez przedsiębiorstwo podejścia etyka biznesu (wyjaśniono 
je w części pierwszej artykułu) jako tego, które intensyfikuje konflikty z podmiotami z otoczenia. W tym podejściu czynnikiem wywołującym zachowania nieetyczne był system wartości przedsiębiorstwa (jako czynnik endogeniczny) oraz istnienie sytuacji konfliktowej będącej skutkiem różnic w interesach przedsiębiorstw (jako czynnik egzogeniczny). W obu podejściach za kryterium etycznego charakteru zachowań przedsiębiorstwa przyjęto zgodność z zasadami sprawiedliwości dystrybutywnej i proceduralnej.

Duże przedsiębiorstwa, które angażują się w relacje z innymi podmiotami, stają w obliczu dylematu: realizować tylko własne cele i interesy, czy, a jeśli tak, to w jakim stopniu, w swoich działaniach uwzględnić również bardziej ogólny interes, w tym mniejszych przedsiębiorstw, z którymi nawiązały relacje? Współdziałanie w ramach takich relacji jest drogą do realizacji celów i zadań zrównoważonego rozwoju. Konsekwencję dokonanych wyborów stanowią określone zachowania, które można ocenić w kategoriach, uwzględniając cztery kluczowe kwestie (Dembinski, 2017, s. 50-51):

(1) Nastawienie przedsiębiorstwa na własną wydajność ekonomiczną. Osiągnięcie własnych celów przedsiębiorstwa stanowi warunek konieczny i wystarczający dla podjęcia rozpatrywanego działania oraz musi być oceniane jako pierwsze. Z punktu widzenia tego kryterium mierzy się i ocenia efekt dla podmiotu, w którym podejmowane są decyzje.

(2) Nastawienie na prawa i zasady. Umożliwia jasne wykazanie, do jakiego stopnia przewidywane (czy zrealizowane) przedsięwzięcie wpłynie (wpłynęło) na istniejący porządek instytucjonalny w przedsiębiorstwie i poza nim.

(3) Nastawienie na rzeczywistą jakość rozpatrywanego działania (w oryginale: „postępku”). To kryterium odnosi działanie do systemu wartości podmiotu podejmującego decyzje. Może dotyczyć etycznych i profesjonalnych aspektów rozpatrywanego działania. Odzwierciedla „przekonanie” podmiotu działającego oraz jego odpowiedzialność za zjawiska, które mu uświadomiono.

(4) Nastawienie na wpływ na osoby trzecie. Jest to kryterium służące do oceny wpływu decyzji na „innych” - tych, poza wąską grupą decydujących, którzy odczują jej konsekwencje. Etyka w podejmowaniu decyzji obejmuje uświadomienie sobie wpływu decyzji na tych, którzy nie mogą nagrodzić ani ukarać podejmującego decyzję, tzn. na tych, którzy „nie mają nic do powiedzenia”. Są oni postrzegani jako pasywni, niemający głosu.

Użyty powyżej w odniesieniu do omawianych kwestii zwrot „nastawienie przedsiębiorstwa" na określoną wartość jest rozumiany jako dominujący wśród decydentów w przedsiębiorstwie pozytywny stosunek do określonej wartości. Nastawienie wyraża się w liczbie i specyfice, w szczególności celach, decyzji podejmowanych $\mathrm{w}$ przedsiębiorstwie. 
Macierz przedstawiona na rysunku 3 obrazuje przestrzeń umożliwiającą ocenę zachowań przedsiębiorstw. Wykorzystuje ją Observatoire de la Finance do m.in. rozważań nad dylematami etycznymi i ich znaczeniem w kulturach organizacyjnych (Dembinski, 2017, s. 51). Jest to wielowymiarowa przestrzeń pozwalająca ocenić skutki etyczne decyzji podejmowanych przez przedsiębiorstwa. Poniżej, odwołując się do wspomnianej macierzy, scharakteryzowano sytuacje, w których mogą znaleźć się przedsiębiorstwa. Uczyniono to, uwzględniając nastawienia ujawniające się w procesach decyzyjnych i zachowaniach przedsiębiorstw. Przeprowadzona analiza odnosi się głównie do relacji między przedsiębiorstwami. Wyniki tej oceny pozwalają zidentyfikować domniemany wpływ sytuacji przedsiębiorstwa na relacje z innymi, w szczególności mniejszymi przedsiębiorstwami, co w późniejszym okresie może skutkować zróżnicowanym stopniem realizacji CZR przez te podmioty.

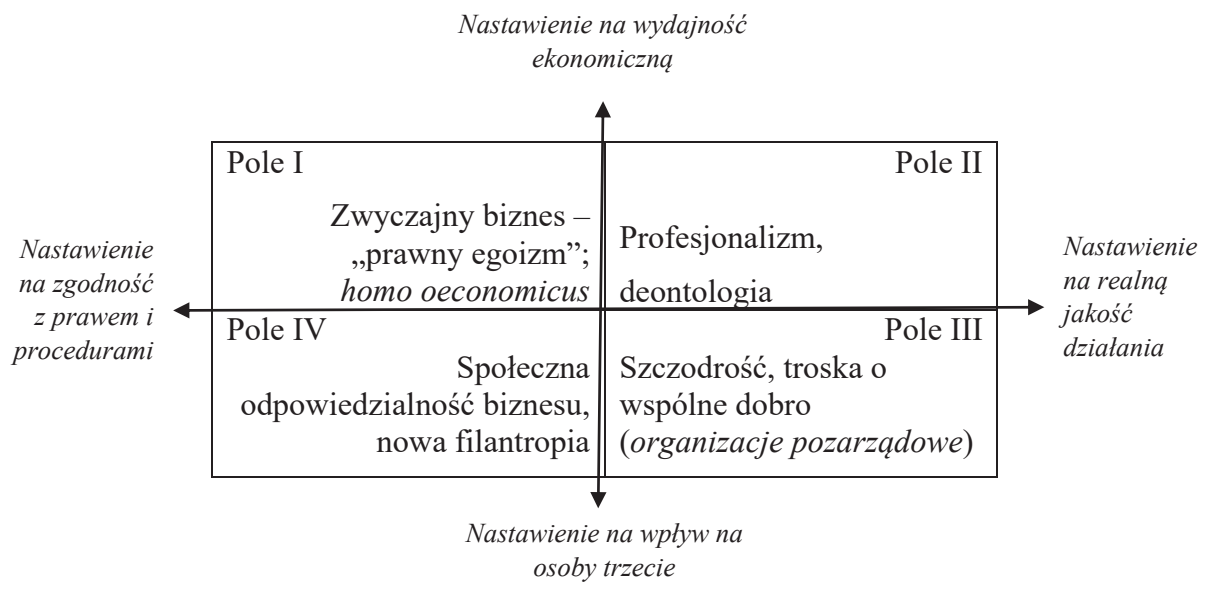

Rysunek 3. Macierz do oceny ekonomicznych i finansowych zachowań przedsiębiorstw w kategoriach etycznych

Źródło: opracowanie własne na podstawie Dembinski, 2017, s. 52. 
Pole I symbolizuje sytuację przedsiębiorstwa, które, łącząc nastawienie na wydajność ekonomiczną z nastawieniem na zgodność z prawem i procedurami, postępuje w sposób, który powszechnie przypisuje się przedsiębiorstwom - dąży do maksymalizacji osiąganego zysku. Jest skupione na własnych wynikach ekonomicznych, które osiąga, ignorując interesy innych podmiotów, a nawet ich kosztem. Podejmowane działania są realizowane zgodnie z obowiązującymi regulacjami, co w kontekście nastawienia na wydajność ekonomiczną może wynikać z obawy przed finansowymi konsekwencjami naruszeń przepisów. Ewentualne oczekiwania wobec przedsiębiorstwa, niemające umocowania w przepisach, są ignorowane, chyba że przynoszą mu odczuwalne korzyści ekonomiczne.

Pole II można interpretować dwojako. Jeżeli opisuje sytuację przedsiębiorstw, które odwołują się do etyki biznesu, to wówczas takie organizacje w trakcie relacji będą dążyć do realizacji własnych korzyści, postrzegając je jako swoją naczelną wartość. Wyrazi się to w podejmowaniu zachowań nastawionych na maksymalizację własnej wydajności ekonomicznej. W konsekwencji należy liczyć się z wystąpieniem konfliktów interesów z mniejszymi przedsiębiorstwami, z którymi nawiązano relacje. Większe przedsiębiorstwo, dążąc do uzyskania jak najlepszych wyników ekonomicznych, będzie skłonne podejmować zachowania obiektywnie szkodzące mniejszym podmiotom, uzasadniając je własnym dobrem. W takim przypadku nastawienie na realną jakość przedsięwzięcia będzie traktowane jako etyczne uzasadnienie podejmowanych działań.

Natomiast gdy przedsiębiorstwo kieruje się podejściem etyka w biznesie, odwołuje się do systemu wartości, który ma źródło poza przedsiębiorstwem i nie preferuje własnych interesów. W tej sytuacji można oczekiwać, że nastawienie na wydajność ekonomiczną będzie zmodyfikowane przez chęć uwzględnienia $\mathrm{w}$ podejmowanych zachowaniach szerszego zestawu wartości, w tym ważnych dla otoczenia przedsiębiorstwa. Większe przedsiębiorstwa znajdujące się w omawianej sytuacji mogą dążyć do uzyskania jak najlepszych wyników ekonomicznych, ale w swoich działaniach będą również uwzględniać interesy innych podmiotów.

Analizując przedsiębiorstwa, których sytuację oznacza pole III, ponownie należy odwołać się do wpływu, jaki na zachowania przedsiębiorstwa ma przyjmowany pogląd na temat relacji między etyką a systemami społecznymi. Gdy przedsiębiorstwo kieruje się podejściem etyka biznesu, można oczekiwać tego, że jego system wartości w ograniczonym stopniu będzie inspirował do podejmowania zachowań skutkujących poprawą sytuacji innych podmiotów. Zarazem należy liczyć się z tym, iż taki system wartości będzie motywował do tego, by prowokować inne podmioty do podejmowania działań pozytywnie wpływających na przedsiębiorstwo. 
Odmiennych zachowań można oczekiwać od przedsiębiorstw, których systemy wartości kierują się etyką w biznesie. W takiej sytuacji można liczyć na to, że system wartości przedsiębiorstwa będzie zachęcał do podejmowania zachowań mogących wywołać poprawę sytuacji innych podmiotów. Można również oczekiwać zachęt dla innych podmiotów do obopólnie korzystnej współpracy z przedsiębiorstwem.

Pole IV symbolizuje przedsiębiorstwa, które w swoim postępowaniu łączą nastawienie na zgodność z prawem z nastawieniem na osoby trzecie. Takie przedsiębiorstwa mogą podejmować zachowania prowadzące do rozwiązywania konkretnych problemów współdziałających podmiotów. Z punktu widzenia interesów tych drugich wydaje się zasadne rozwiązywanie problemów powodujących ograniczanie możliwości rozwojowych. Omawiane zachowania mogą w szczególności pomagać pokonywać ograniczenia zasobowe. Ponadto przedsiębiorstwa o cechach właściwych dla pola IV mogą w ramach nawiązanych relacji stosować takie formy współpracy, które wpływają na poprawę sytuacji finansowej mniejszych podmiotów. W swoim postępowaniu opisywane przedsiębiorstwa kierują się zasadami i regułami prawa.

W tabeli 3 opisano potencjalne konsekwencje kierowania się przez przedsiębiorstwa omówionymi nastawieniami w relacjach $\mathrm{z}$ innymi podmiotami, z reguły mniejszymi od nich, w kontekście wskazanych w części trzeciej artykułu zadań zrównoważonego rozwoju. Sytuacje przedsiębiorstw badano, odwołując się do pól określonych na rysunku 3. Identyfikując możliwe skutki zachowań przedsiębiorstw, w których sytuacji występuje komponent w postaci nastawienia na realną jakość działania (pole II i pole III), uwzględniono fakt, że przedsiębiorstwa w ich systemach wartości mogą kierować się odwołaniem do etyki biznesu lub etyki w biznesie. Kryterium zaliczenia zachowań przedsiębiorstwa do nieetycznych, które w tabeli 3 zaznaczono kursywą, stanowi niezgodność z zasadami sprawiedliwości dystrybutywnej i proceduralnej. 
Tabela 3. Możliwe zachowania przedsiębiorstw wynikające z ich nastawień, związane z realizacją zadań zrównoważonego rozwoju (kursywą zaznaczono zachowania uznane za nieetyczne)

\begin{tabular}{cl}
\hline Zadanie & Możliwe zachowania przedsiębiorstw w związku z realizacją zadań zrównoważonego rozwoju \\
\hline Pole I \\
\hline 8.2. & • próby przenoszenia ryzyka i kosztów działalności na partnerów (mniejsze przedsiębiorstwa), \\
& - zlecanie prac o niskiej wartości dodanej, \\
• zlecanie prac hamujących rozwój kompetencji przedsiębiorstwa przyjmującego zlecenie
\end{tabular}

8.3. - zlecanie prac, które (a) nie wymagają od mniejszych przedsiębiorstw angażowania wyróżniajacych zasobów, w tym kompetencji, (b) petryfikują aktualną sytuację mniejszych przedsiębiorstw z punktu widzenia stanu zasobów i obstugiwanych rynków

9.3. - angażowanie do działań w tych ogniwach łańcuchów wartości, które (a) generują najmniej wartości, (b) utrudniaja ksztattowanie i upowszechnianie pożądanego wizerunku mniejszego przedsiębiorstwa

10.3. - stosowanie praktyk typu value extraction przy zapewnieniu sobie podstaw prawnych (np. w zawartych umowach) do ich podejmowania,

- uzależnianie zlecenia wykonania prac/operacji od spelnienia określonych oczekiwań dużego przedsiębiorstwa (np. kosztowych, dotyczacych gwarancji) przez mniejszy podmiot

12.6. - ograniczenie stosowania praktyk z zakresu zrównoważonego rozwoju do takich, które nie wplywają negatywnie na wydajność ekonomiczną przedsiębiorstw

16.1. - stosowanie przemocy symbolicznej w relacjach ze słabszymi przedsiębiorstwami w celu ukształtowania korzystnych form i treści relacji z mniejszymi przedsiębiorstwami

\section{Pole II - Przedsiębiorstwa odwołujące się do etyki biznesu}

8.2. - przerzucanie niektórych kosztów na współdziałające przedsiębiorstwa,

- zlecanie prac generujacych niewspólmiernie niskie dochody w stosunku do wysiłku mniejszych podmiotów,

- utrudnianie rozwoju potencjału mniejszych podmiotów z obawy, że moga stać się silnymi konkurentami,

- utrudnianie dostęp do know-how

8.3. - utrudnianie rozwoju mniejszych przedsiębiorstw wynikające z chęci uniemożliwienia rozwoju silnego konkurenta (chęć petryfikacji sytuacji mniejszych podmiotów)

9.3. - włączanie mniejszych przedsiębiorstw we własne łańcuchy wartości do realizacji najmniej atrakcyjnych aktywności

10.3. - stosowanie praktyk dyskryminujących małe przedsiębiorstwa,

- uzależnienie nawiązywania i utrzymywania relacji od spetnienia oczekiwań dużego przedsiębiorstwa, w szczególności przynoszących skutki finansowe

12.6. - unikanie stosowania tych praktyk z zakresu zróżnicowanego rozwoju, które wywierałyby negatywny wpływ na wydajność ekonomiczna przedsiębiorstwa

16.1. - stosowanie przemocy ekonomicznej i symbolicznej w relacjach ze słabszymi podmiotami

Pole II - Przedsiębiorstwa odwołujące się do etyki w biznesie

8.2. - zlecanie prac (a) umożliwiających rozwój mniejszych przedsiębiorstw, (b) wykorzystujących wyróżniające zasoby, w tym kompetencje mniejszych przedsiębiorstw,

- dostarczanie know-how umożliwiającego realizację aktywności o większej wartości dodanej,

- proporcjonalny do skali aktywności udział w ponoszeniu kosztów 
Zadanie Możliwe zachowania przedsiębiorstw w związku z realizacją zadań zrównoważonego rozwoju

8.3. - zlecanie operacji (a) wymagających zaangażowania wyróżniających zasobów małych przedsiębiorstw, (b) stwarzających możliwości rozwoju zasobów, w tym kompetencji,

- włączanie do własnych prac badawczo-rozwojowych pracowników mniejszych przedsiębiorstw,

- dokonywanie transferu technologii do mniejszych przedsiębiorstw

9.3. - włączanie mniejszych przedsiębiorstw do aktywności w tych ogniwach łańcuchów wartości, które w największym stopniu angażują ich wyróżniające zasoby,

- stwarzanie warunków do lepszej rozpoznawalności i kształtowania wizerunku mniejszych przedsiębiorstw

10.3. - kształtowanie partnerskich i równoprawnych relacji z innymi przedsiębiorstwami

12.6. - stosowanie praktyk z zakresu zrównoważonego rozwoju, nawet gdyby zmniejszały tempo wzrostu wydajności ekonomicznej przedsiębiorstwa

16.1. - unikanie przemocy, nawet symbolicznej

Pole III - Przedsiębiorstwa odwołujące się do etyki biznesu

8.2. - ograniczanie angażowania się w relacje z innymi przedsiębiorstwami jako zasada postępowania,

- unikanie angażowania się w relacje, z których miałyby wynikać jakieś formy pomocy dla innych przedsiębiorstw

8.3. - bardzo ograniczona współpraca z innymi podmiotami, np. formułowanie zachęt werbalnych, raczej obliczonych na wywołanie efektu w otoczeniu (kształtowanie wizerunku),

- symboliczne formy pomocy innym przedsiębiorstwom, nastawione raczej na wywołanie pozytywnych skojarzeń w otoczeniu

9.3. - minimalizowanie zakresu wspólnych przedsięwzięć (np. prowadzenia działalności w łańcuchu wartości, wspólnego występowania na rynku) - raczej, by stworzyć wrażenie udzielania pomocy, niż realnie pomagać

10.3. - deklarowanie podejmowania działań zapewniających równorzędną pozycję partnerom, ograniczanie realnych działań

12.6. - deklarowanie podejmowania praktyk z zakresu zrównoważonego rozwoju, realne działania mają charakter wybiórczy i ograniczający obciążenia dla przedsiębiorstwa

16.1. - deklarowanie rezygnacji ze stosowania jakichkolwiek form przemocy, dyskretne posługiwanie się przemocą symboliczną

Pole III - Przedsiębiorstwa odwołujące się do etyki w biznesie

8.2. - zlecanie aktywności i prac umożliwiających partnerom przedsiębiorstwa rozwój zasobów, w tym kompetencji i zdolności,

- dostarczanie partnerom know-how pozwalającego realizować bardziej wartościotwórcze aktywności,

- obciążanie partnerów kosztami tylko w koniecznym zakresie

8.3. - ułatwianie partnerom podejmowania działalności gospodarczej,

- udostępnianie własnych zasobów materialnych i niematerialnych po najniższych, ekonomicznie uzasadnionych kosztach (np. rezygnacja z marży),

- wspólne przedsięwzięcia nastawione na kreowanie innowacji

9.3. - włączanie mniejszych przedsiębiorstw do własnych łańcuchów wartości bez stawiania warunków wstępnych nieodnoszących się do samej działalności

10.3. - nawiązywanie relacji na zasadzie partnerstwa i równorzędności

12.6. - spontaniczne wdrażanie praktyk z zakresu zrównoważonego rozwoju

16.1. - unikanie stosowania jakichkolwiek form przemocy w relacjach $\mathrm{z}$ innymi podmiotami 


\begin{tabular}{|c|c|}
\hline Zadanie & Możliwe zachowania przedsiębiorstw w związku z realizacją zadań zrównoważonego rozwoju \\
\hline \multicolumn{2}{|r|}{ Pole IV } \\
\hline 8.2. & $\begin{array}{l}\text { - odczuwanie przez przedsiębiorstwo odpowiedzialność za sytuację swoich interesariuszy, w szcze- } \\
\text { gólności współpracujących przedsiębiorstw, } \\
\text { - udostępnianie swojego know-how mniejszym przedsiębiorstwom, } \\
\text { - solidarne z mniejszymi przedsiębiorstwami ponoszenie kosztów wspólnie prowadzonej dzia- } \\
\text { łalności, } \\
\text { - zlecanie prowadzenia aktywności atrakcyjnych z punktu widzenia krótkiego (ze względu na war- } \\
\text { tość dodaną) i długiego okresu (ze względu na rozwijanie potencjału przedsiębiorstwa) }\end{array}$ \\
\hline 8.3 . & $\begin{array}{l}\text { - ułatwianie małym przedsiębiorstwom podejmowania działalności skutkujących poprawą sytu- } \\
\text { acji ich pracowników, } \\
\text { - wspieranie przedsięwzięć prowadzących do wieloaspektowego doskonalenia działalności mniej- } \\
\text { szych przedsiębiorstw }\end{array}$ \\
\hline 9.3. & $\begin{array}{l}\text { - włączanie do swoich łańcuchów wartości według niedyskryminujących zasad, } \\
\text { - unikanie stosowania w nawiązywanych relacjach praktyk dyskryminujących jakiekolwiek pod- } \\
\text { mioty, w szczególności mniejsze }\end{array}$ \\
\hline 10.3. & $\begin{array}{l}\text { - nawiązywanie relacji na podstawie jasnych zasad (m.in. równorzędność, brak dyskryminacji), } \\
\text { publicznie deklarowanych i konsekwentnie stosowanych }\end{array}$ \\
\hline 12.6. & - spontaniczne i konsekwentne wdrażanie praktyk z zakresu zrównoważonego rozwoju \\
\hline 16.1. & $\begin{array}{l}\text { - pryncypialne odrzucanie stosowania przemocy w relacjach z innymi podmiotami, w tym przed- } \\
\text { siębiorstwami }\end{array}$ \\
\hline
\end{tabular}

Źródło: opracowanie własne.

Można sądzić, że częstotliwość podejmowania zachowań wskazanych w tabeli 3 jest zróżnicowana, co stanowi konsekwencję faktu, iż przedsiębiorstwa różnią się między sobą m.in. przyjmowanymi nastawieniami, które z reguły są specyficzne w każdej organizacji. Wśród możliwych zachowań przedsiębiorstw wymienionych w tabeli 3, z punktu widzenia sprzyjania realizacji zadań zrównoważonego rozwoju, można wyróżnić zachowania: (a) sprzyjające, (b) niesprzyjające, (c) neutralne, z których tylko należące do drugiej grupy będą przedmiotem dalszego zainteresowania. Do tej grupy należy zaliczyć przede wszystkim te zachowania, które zaznaczono jako nieetyczne. Zostały tak ocenione ze względu na to, iż powodują brak sprawiedliwości dystrybutywnej w trakcie podziału wartości wygenerowanej w trakcie współdziałania. Ponadto, rzadziej, ma miejsce brak sprawiedliwości proceduralnej, którego efektem może być brak sprawiedliwości dystrybutywnej. Cechą charakterystyczną przedsiębiorstw mogących stosować takie zachowania jest w pierwszej kolejności nastawienie na własną wydajność ekonomiczną. Przedsiębiorstwa o zestawie nastawień właściwym dla pola I dążą do osiągnięcia wydajności ekonomicznej zgodnie z prawem, dlatego zachowania nieetyczne mogą postrzegać jako komplementarny w stosunku do „normalnego” biznesu sposób poprawy własnych wyników, nienarażający ich na sankcje prawne. 
Kolejnych zachowań nieetycznych można spodziewać się w działaniach przedsiębiorstw, których nastawienia są właściwe dla pola II, ale wtedy gdy przedsiębiorstwo w swoim systemie wartości odwołuje się do etyki biznesu. W przedsiębiorstwach o takim zestawie nastawień, nastawienie na wydajność ekonomiczną łączy się z orientacją na rzeczywistą jakość zachowań, ale wynikającą z ich wewnętrznego systemu wartości. W takiej sytuacji przedsiębiorstwo dąży do osiągnięcia celów ekonomicznych, a za kryterium oceny swoich zachowań - z punktu widzenia etyki - przyjmuje to, w jakim stopniu przyczyniają się one do poprawy stopnia realizacji celów przedsiębiorstwa. W opisywanym przypadku zachowania, które z punktu widzenia egzogenicznego systemu wartości są postrzegane jako nieetyczne, przedsiębiorstwo postrzega jako etyczne. Niezależnie od ocen sformułowanych przez przedsiębiorstwa, omawiane zachowania podważają możliwość realizacji CZR.

W wybranych, spośród wskazanych przez Dembinskiego (2012), obszarach konfliktów (por. część pierwszą artykułu) występują szczególne zachęty do nieetycznych zachowań, ponieważ mogą być one postrzegane jako względnie łatwe i dające szybkie efekty sposoby na zapewnienie sobie przez przedsiębiorstwo rozstrzygnięcia konfliktu na własną korzyść. Dlatego przedsiębiorstwa, które znajdują się w sytuacjach umożliwiających podejmowanie zachowań nieetycznych, mogą względnie łatwo zdecydować się na ich podjęcie. $Z$ tego powodu potencjalną łatwość podjęcia zachowań można uznać za przesłankę do identyfikacji kluczowych zachowań nieetycznych wpływających na realizację celów i zadań zrównoważonego rozwoju, podejmowanych w obszarach konfliktów, które wyróżniono w tabeli 1 (s. 12).

Analizując i oceniając zachowania ujęte w tabeli 3, stwierdzono, że te, które negatywnie wpływają na realizację CZR i wynikających z nich zadań, są konsekwencją odwoływania się przez przedsiębiorstwa w ich systemach wartości do opisanego już podejścia etyka biznesu. Dlatego dalsze poszukiwanie obszaru potencjalnie nieetycznych zachowań przedsiębiorstw zawężono do tych, które są konsekwencją tego podejścia. W tabeli 4 wskazano takie zachowania. Komórki tabeli odpowiadają na pytanie: jakie zachowania nieetyczne mogą mieć miejsce w powiązaniu z poszczególnymi obszarami konfliktu, w sytuacjach opisanych na rysunkach 1 i 2, w związku z realizacją określonych zadań zrównoważonego rozwoju? Poszukując zachowań potencjalnie nieetycznych, zastosowano założenie upraszczające, polegające na tym, że przedsiębiorstwami, o których się sądzi, iż zachowują się nieetycznie, są duże przedsiębiorstwa, mające silną pozycję przetargową $\mathrm{w}$ stosunku do innych podmiotów. Natomiast narażonymi na zachowania nieetyczne są przedsiębiorstwa mniejsze - małe i średnie. Uproszczenie bierze się stąd, że analizowane CZR są z reguły ukierunkowane na poprawę sytuacji 
mniejszych przedsiębiorstw, zaś podmiotami, które miałyby ułatwić osiągnięcie tych celów, są duże przedsiębiorstwa (tylko w wyjątkowych sytuacjach mogą to nie być duże podmioty), stąd są one w sytuacji poniekąd uprzywilejowanej, gdyż uzależniając od siebie małe podmioty, stwarzają sobie okazje do zachowań nieetycznych, by rozstrzygnąć konflikty na swoją korzyść.

Tabela 4. Możliwe zachowania nieetyczne w różnych obszarach konfliktu, związane z realizacją zadań zrównoważonego rozwoju

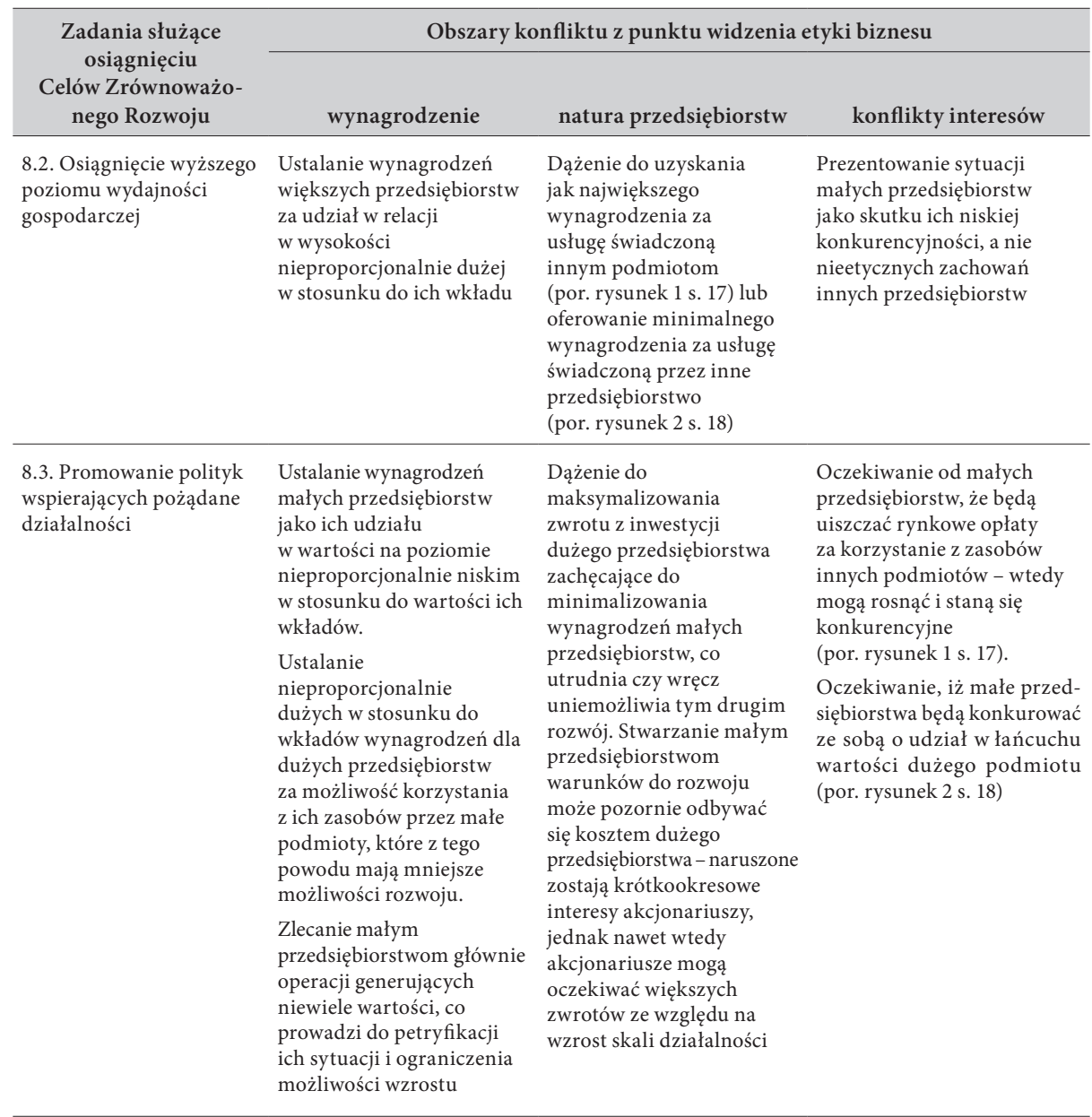




\begin{tabular}{|c|c|c|c|}
\hline \multirow{2}{*}{$\begin{array}{l}\text { Zadania służące } \\
\text { osiągnięciu } \\
\text { Celów Zrównoważo- } \\
\text { nego Rozwoju }\end{array}$} & \multicolumn{3}{|c|}{ Obszary konfliktu z punktu widzenia etyki biznesu } \\
\hline & wynagrodzenie & natura przedsiębiorstw & konflikty interesów \\
\hline $\begin{array}{l}\text { 9.3. Zwiększenie dostępu } \\
\text { przedsiębiorstw do } \\
\text { łańcuchów wartości, } \\
\text { zapewnienie udziału } \\
\text { w rynku }\end{array}$ & $\begin{array}{l}\text { Ustalanie wynagrodzeń dla } \\
\text { małych przedsiębiorstw na } \\
\text { poziomie niewspółmiernie } \\
\text { niskim w stosunku do } \\
\text { wkładów ogranicza ich } \\
\text { możliwości rozwoju. } \\
\text { Problemem jest sposób } \\
\text { ustalania wynagrodzenia } \\
\text { dla przedsiębiorstw, które } \\
\text { włącza się w łańcuch } \\
\text { wartości }\end{array}$ & $\begin{array}{l}\text { Dążenie do maksymalizacji } \\
\text { zwrotu z inwestycji dużego } \\
\text { przedsiębiorstwa, które } \\
\text { prowadzi do wypłat dla } \\
\text { mniejszych przedsiębiorstw } \\
\text { nieproporcjonalnie } \\
\text { małych w stosunku do ich } \\
\text { wkładów, co ogranicza } \\
\text { możliwości rozwoju tych } \\
\text { drugich }\end{array}$ & $\begin{array}{l}\text { Ustalanie niesprawiedliwego } \\
\text { wynagrodzenia jako } \\
\text { skutku przewagi dużego } \\
\text { przedsiębiorstwa - } \\
\text { wykorzystanie silniejszej } \\
\text { pozycji przetargowej. } \\
\text { Konflikt interesów powoduje } \\
\text { nieproporcjonalny podział } \\
\text { wygenerowanej wartości } \\
\text { między duże i małe } \\
\text { przedsiębiorstwa }\end{array}$ \\
\hline $\begin{array}{l}\text { 10.3. Zapewnienie } \\
\text { równych szans }\end{array}$ & $\begin{array}{l}\text { Wykorzystywanie } \\
\text { silniejszej pozycji } \\
\text { przetargowej wobec } \\
\text { małych przedsiębiorstw } \\
\text { i ich uzależnienia przez } \\
\text { duże przedsiębiorstwa } \\
\text { daje dużym podmiotom } \\
\text { możliwość uzyskiwania } \\
\text { wynagrodzeń } \\
\text { nieproporcjonalnie dużych } \\
\text { w stosunku do ich wkładów } \\
\text { w generowanie wartości }\end{array}$ & $\begin{array}{l}\text { Wykorzystywanie } \\
\text { silniejszej pozycji } \\
\text { przetargowej wobec } \\
\text { małych przedsiębiorstw } \\
\text { i ich uzależnienia przez } \\
\text { duże przedsiębiorstwa } \\
\text { daje im możliwość } \\
\text { maksymalizowania } \\
\text { zwrotów z poczynionych } \\
\text { inwestycji }\end{array}$ & $\begin{array}{l}\text { Odwoływanie się do } \\
\text { konkurencji i mechanizmu } \\
\text { rynkowego przy } \\
\text { kształtowaniu przez duże } \\
\text { przedsiębiorstwa relacji } \\
\text { z małymi podmiotami, } \\
\text { co utrudnia zapewnienie } \\
\text { równych szans i likwidację } \\
\text { nierówności w sytuacji } \\
\text { istnienia różnic pozycji } \\
\text { przetargowej }\end{array}$ \\
\hline $\begin{array}{l}\text { 12.6. Zachęcanie } \\
\text { do wdrażania } \\
\text { praktyk z zakresu } \\
\text { zrównoważonego rozwoju }\end{array}$ & $\begin{array}{l}\text { Dysponowanie silniejszą } \\
\text { pozycją przetargową wobec } \\
\text { małych przedsiębiorstw } \\
\text { i warunkami do ich } \\
\text { uzależnienia przez duże } \\
\text { przedsiębiorstwa może nie } \\
\text { zachęcać do wdrażania } \\
\text { praktyk z zakresu } \\
\text { zrównoważonego rozwoju, } \\
\text { jeśli nie wpływają na } \\
\text { wielkość uzyskiwanego } \\
\text { wynagrodzenia }\end{array}$ & $\begin{array}{l}\text { Skłonność dużych } \\
\text { przedsiębiorstw do } \\
\text { angażowania się we } \\
\text { wdrażanie praktyk } \\
\text { z zakresu zrównoważonego } \\
\text { rozwoju, jeżeli wskutek } \\
\text { poprawy wizerunku } \\
\text { oczekują wzrostu zwrotu } \\
\text { z inwestycji }\end{array}$ & $\begin{array}{l}\text { Instrumentalne traktowanie } \\
\text { relacji z mniejszymi } \\
\text { przedsiębiorstwami lub } \\
\text { nawiązywanie pozornych } \\
\text { relacji w celu wykorzystania } \\
\text { ich do kreowania } \\
\text { wizerunku przedsiębiorstwa } \\
\text { zaangażowanego we } \\
\text { wdrażanie praktyk z zakresu } \\
\text { zrównoważonego rozwoju }\end{array}$ \\
\hline $\begin{array}{l}\text { 16.1. Zmniejszenie } \\
\text { poziomu przemocy }\end{array}$ & $\begin{array}{l}\text { Stosowanie przez duże } \\
\text { przedsiębiorstwa przemocy } \\
\text { symbolicznej w celu } \\
\text { zwiększania wynagrodzeń } \\
\text { za udział w relacjach } \\
\text { z małymi podmiotami. } \\
\text { Przedsiębiorstwa mogą } \\
\text { podejmować zachowania } \\
\text { „przemocowe”, } \\
\text { jeżeli z jakichś względów } \\
\text { uważają je za przynoszące } \\
\text { np. większy udział } \\
\text { w wartości }\end{array}$ & $\begin{array}{l}\text { Zastosowanie niejawnej } \\
\text { przemocy symbolicznej } \\
\text { w celu maksymalizowania } \\
\text { zwrotu z poczynionych } \\
\text { inwestycji drogą } \\
\text { zwiększania przychodów } \\
\text { i zysków }\end{array}$ & $\begin{array}{l}\text { Wykorzystanie przemocy } \\
\text { przez duże przedsiębiorstwo } \\
\text { (z silniejszą pozycją } \\
\text { negocjacyjną) do } \\
\text { rozstrzygania konfliktów } \\
\text { w relacjach z partnerami }\end{array}$ \\
\hline
\end{tabular}

Źródło: opracowanie własne. 
Wskazane w tabeli 4 zachowania nieetyczne różnią się charakterem. Te, które są związane z pierwszym z obszarów konfliktów, naruszają przede wszystkim zasady sprawiedliwości dystrybutywnej i skutkują niesprawiedliwym podziałem wartości generowanej przez współpracujące przedsiębiorstwa, którą, w tym kontekście, można określić wynagrodzeniem za aktywność w generowaniu wartości. Natomiast zachowania nieetyczne - zidentyfikowane jako związane z naturą przedsiębiorstw - to głównie zachowania skutkujące brakiem sprawiedliwości proceduralnej, polegające na braku równorzędności między podmiotami, wskutek czego większe podmioty zapewniają sobie silniejszą pozycję w relacjach z mniejszymi podmiotami. To zaś umożliwia im zapewnienie korzystniejszych zapisów w zawieranych umowach. Podobnie wygląda sytuacja w trzecim obszarze konfliktów - tu dominuje brak sprawiedliwości proceduralnej, wyrażający się w braku równości w relacjach oraz narzucaniem słabszym podmiotom trudnych do spełnienia warunków.

Jak wskazano w części trzeciej artykułu, sektor prywatny pełni kluczową rolę w realizacji CZR, dlatego identyfikując możliwe zachowania nieetyczne, stanowiące zagrożenie dla zrównoważonego rozwoju, należy zwrócić uwagę na bloki zawierające rekomendacje dla tego sektora. Ze względu na fakt, że podmioty należące do sektora prywatnego są narażone na sytuacje konfliktowe, poniższą analizę również przeprowadzono, uwzględniając wybrane obszary konfliktów. $\mathrm{W}$ tabeli 5 zaprezentowano potencjalne zachowania nieetyczne przedsiębiorstw, które mogą być podejmowane przy okazji wykonywania zadań w obrębie głównych bloków rekomendowanych dla sektora prywatnego w związku z realizacją zadań zrównoważonego rozwoju. Podobnie jak w tabeli 4, skupiono się na podejściu etyka biznesu jako tym, które przede wszystkim generuje zachowania nieetyczne, oraz odniesiono się do omówionych już obszarów konfliktu, ponieważ mogą one być asumptem do podejmowania takich zachowań. Również w tym przypadku kryterium służącym do identyfikacji zachowań nieetycznych jest niezgodność z zasadami sprawiedliwości dystrybutywnej i proceduralnej. 
Tabela 5. Możliwe zachowania nieetyczne w blokach obszarów rekomendacji dla sektora prywatnego

\begin{tabular}{|c|c|c|c|}
\hline \multirow{2}{*}{$\begin{array}{l}\text { Główne bloki obszarów } \\
\text { rekomendacji dla sektora } \\
\text { prywatnego }\end{array}$} & \multicolumn{3}{|c|}{ Obszar konfliktu z punktu widzenia etyki biznesu } \\
\hline & wynagrodzenie & natura przedsiębiorstw & konflikty interesów \\
\hline $\begin{array}{l}\text { W bloku I: } \\
\text { włączenie najbiedniej- } \\
\text { szego miliarda ludzi } \\
\text { w globalny system eko- } \\
\text { nomiczny }\end{array}$ & $\begin{array}{l}\text { Przedsiębiorstwa } \\
\text { włączające w swoje } \\
\text { łańcuchy wartości } \\
\text { ludzi znajdujących się } \\
\text { w sytuacji przymusu } \\
\text { ekonomicznego } \\
\text { mogą ustalać dla } \\
\text { nich wynagrodzenia } \\
\text { nieproporcjonalnie } \\
\text { niskie w stosunku do ich } \\
\text { wkładu w wygenerowanie } \\
\text { wartości, co skutkuje } \\
\text { niewielką poprawą ich } \\
\text { sytuacji i pozostawaniem } \\
\text { w stanie biedy }\end{array}$ & $\begin{array}{l}\text { Duże przedsiębiorstwa, } \\
\text { kierując się chęcią } \\
\text { maksymalizacji zwrotu } \\
\text { z inwestycji i włączając } \\
\text { ludzi znajdujących się } \\
\text { w sytuacji przymusu } \\
\text { ekonomicznego do swoich } \\
\text { łańcuchów wartości } \\
\text { (por. rysunek } 2 \text { s. 18) } \\
\text { lub czyniąc ich swoimi } \\
\text { dostawcami, mogą: } \\
\text { (a) ustalać zaniżone } \\
\text { wynagrodzenia, } \\
\text { (b) przenosić niektóre } \\
\text { koszty na podmioty } \\
\text { włączane do łańcuchów } \\
\text { wartości, } \\
\text { (c) formułować } \\
\text { oczekiwania, które } \\
\text { w normalnych relacjach } \\
\text { biznesowych nie są } \\
\text { stawiane }\end{array}$ & $\begin{array}{l}\text { Odwoływanie się } \\
\text { do konkurencji jako } \\
\text { kryterium ustalania } \\
\text { warunków współpracy } \\
\text { z przedsiębiorstwami, } \\
\text { które stają się dostawcami } \\
\text { dużych podmiotów, może } \\
\text { być metodą obniżania } \\
\text { kosztów nabywanych } \\
\text { usług i wyrobów }\end{array}$ \\
\hline
\end{tabular}

Monitorowanie łańcuchów dostaw w celu wyeliminowania nielegalnych praktyk
Duże przedsiębiorstwa mogą stwarzać asymetrię informacyjną, która utrudnia dostęp do informacji o ewentualnych nielegalnych praktykach
Wspieranie mniejszych organizacji przez duże w procesie ich rozwoju

\begin{tabular}{|c|c|c|}
\hline $\begin{array}{l}\text { Wspieranie mniejszych } \\
\text { organizacji może } \\
\text { polegać na włączeniu ich } \\
\text { w procesy generowania } \\
\text { wartości przez duże } \\
\text { podmioty, jednak } \\
\text { nieuzasadnione } \\
\text { zawyżanie } \\
\text { wynagrodzeń tych } \\
\text { drugich uniemożliwia } \\
\text { rozwój mniejszych } \\
\text { przedsiębiorstw }\end{array}$ & $\begin{array}{l}\text { Duże przedsiębiorstwa, } \\
\text { które uzależniają } \\
\text { od siebie mniejsze, } \\
\text { mogą tworzyć } \\
\text { ugrupowania kierowane } \\
\text { przez siebie jako } \\
\text { "dyrygenta”, stwarzając } \\
\text { mniejszym możliwość } \\
\text { funkcjonowania „pod } \\
\text { skrzydłami” dużych, ale } \\
\text { zarazem wykorzystują je } \\
\text { do zwiększania swoich } \\
\text { zwrotów z inwestycji }\end{array}$ & $\begin{array}{l}\text { Nawiązanie relacji } \\
\text { z niekonkurencyjnymi } \\
\text { małymi } \\
\text { przedsiębiorstwami } \\
\text { przez duże może } \\
\text { być pomocne w ich } \\
\text { rozwoju, ale zarazem } \\
\text { ułatwia ograniczanie } \\
\text { stosowania rynkowych } \\
\text { reguł ustalania } \\
\text { warunków współpracy } \\
\text { i nadużywanie pozycji } \\
\text { przez duże podmioty }\end{array}$ \\
\hline
\end{tabular}

Wspieranie mniejszych organizacji może polegać na włączeniu ich podmioty, jednak nieuzasadnione zawyżanie drugich uniemożliwi rozwój mniejszych przedsiębiorstw 


\begin{tabular}{|c|c|c|c|}
\hline \multirow{2}{*}{$\begin{array}{l}\text { Główne bloki obszarów } \\
\text { rekomendacji dla sektora } \\
\text { prywatnego }\end{array}$} & \multicolumn{3}{|c|}{ Obszar konfliktu z punktu widzenia etyki biznesu } \\
\hline & wynagrodzenie & natura przedsiębiorstw & konflikty interesów \\
\hline $\begin{array}{l}\text { W bloku IV: } \\
\text { przestrzeganie praw } \\
\text { człowieka oraz } \\
\text { monitorowanie } \\
\text { łańcuchów dostaw, } \\
\text { ograniczające } \\
\text { udział nieuczciwej } \\
\text { konkurencji związanej } \\
\text { z wyzyskiem osób }\end{array}$ & $\begin{array}{l}\text { Wykorzystanie zasad } \\
\text { ustalania wynagrodzeń } \\
\text { dla uczestników } \\
\text { łańcuchów wartości } \\
\text { jako narzędzia } \\
\text { wyzysku, ustalanie } \\
\text { nieproporcjonalnie } \\
\text { niskich wynagrodzeń } \\
\text { dla przedsiębiorstw } \\
\text { włączanych do łańcuchów } \\
\text { wartości skutkuje niskimi } \\
\text { wynagrodzeniami } \\
\text { pracowników }\end{array}$ & $\begin{array}{l}\text { Maksymalizacja zwrotu } \\
\text { jest możliwa m.in. dzięki } \\
\text { nieuczciwej konkurencji, } \\
\text { stosowaniu wyzysku } \\
\text { wobec uczestników } \\
\text { łańcuchów wartości, } \\
\text { zarówno wobec } \\
\text { przedsiębiorstw, jak } \\
\text { i osób fizycznych }\end{array}$ & $\begin{array}{l}\text { Konflikty interesów } \\
\text { między organizatorem } \\
\text { łańcucha wartości } \\
\text { a podmiotami, które } \\
\text { są do niego włączane, } \\
\text { mogą być rozstrzygane } \\
\text { drogą wykorzystania } \\
\text { przewagi negocjacyjnej } \\
\text { organizatora łańcucha }\end{array}$ \\
\hline
\end{tabular}

Źródło: opracowanie własne.

W pierwszym $z$ analizowanych obszarów konfliktowych dominują zachowania nieetyczne będące konsekwencją naruszenia zasad sprawiedliwości dystrybutywnej. Niedostateczne przestrzeganie zasad tego typu sprawiedliwości skutkuje uzyskiwaniem przez większe przedsiębiorstwa wynagrodzeń, które są nieproporcjonalnie duże w stosunku do ich wkładu w generowanie wartości. W drugim $\mathrm{z}$ analizowanych obszarów konfliktów dominują zachowania naruszające przede wszystkim zasady sprawiedliwości proceduralnej, co wyraża się głównie brakiem równości stron relacji, co z kolei stwarza później warunki do naruszenia zasad sprawiedliwości dystrybutywnej. W trzecim obszarze konfliktów również dominuje brak sprawiedliwości proceduralnej wyrażający się niedostatkiem rzeczywistej równości stron uczestniczących w relacjach i wykorzystywaniem siły przetargowej przez większe przedsiębiorstwa.

Uogólniając sformułowane powyżej spostrzeżenia, należy stwierdzić, że możliwe zachowania nieetyczne przedsiębiorstw wyrażałyby się przede wszystkim w naruszaniu zasad sprawiedliwości dystrybutywnej w postaci zawyżania wynagrodzeń dużych przedsiębiorstw oraz zaniżania wynagrodzeń przedsiębiorstw mniejszych. Ponadto należy dostrzec zachowania naruszające zasady sprawiedliwości proceduralnej przybierające postać głównie braku równorzędności w relacjach między przedsiębiorstwami dużymi i mniejszymi. Jednak ten brak równorzędności należy potraktować jako instrumentalny, bowiem jest on wykorzystywany do narzucania mniejszym podmiotom takich warunków relacji, które premiują większe przedsiębiorstwa. 
5. Ograniczanie zagrożenia niektórymi zachowaniami nieetycznymi

Wydaje się, że kluczowym zjawiskiem, które wpływa na charakter zachowań w relacjach między przedsiębiorstwami, są stosowane zasady ustalania wynagrodzeń dla współdziałających przedsiębiorstw. Wspomniane zasady przyczyniają się zarazem do podejmowania zachowań nieetycznych. Takie zachowania dużych przedsiębiorstw stają się możliwe dzięki silniejszej pozycji przetargowej, jaką mają one wobec mniejszych podmiotów. Jak wskazano w części drugiej artykułu, komentując modele na rysunkach 1 i 2 , sytuację mniejszych przedsiębiorstw cechuje z reguły trudność w generowaniu wartości w pożądanych rozmiarach. Aby pokonać te ograniczenia, mniejsze przedsiębiorstwa są skłonne tolerować skutki przewag większych podmiotów, w tym zachowania nieetyczne podejmowane w związku z ustalaniem zasad wynagradzania. Można podejrzewać, że istnieje sekwencja: (1) działania nieetyczne z punktu widzenia sprawiedliwości proceduralnej; (2) zawieranie kontraktów traktujących w sposób nierównorzędny jego uczestników; (3) działania nieetyczne z punktu widzenia sprawiedliwości dystrybutywnej, w wyniku czego większe przedsiębiorstwo uzyskuje niewspółmiernie duży udział w trakcie podziału wygenerowanej wartości. Opisany ciąg zjawisk przedstawiono na rysunku 4.

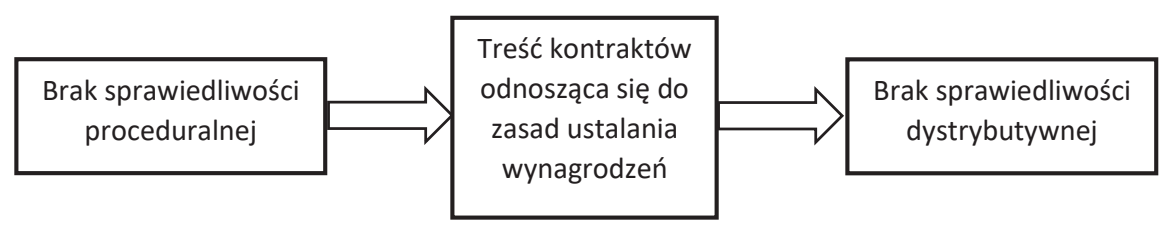

Rysunek 4. Związek zasad ustalania wynagrodzeń z zachowaniami nieetycznymi Źródło: opracowanie własne.

Odwołując się do powyższej sekwencji, jako sposób na ograniczenie ilości zachowań nieetycznych podejmowanych przez duże przedsiębiorstwa wobec małych, a tym samym zmniejszenie zagrożeń dla realizacji celów i zadań zrównoważonego rozwoju, należy wskazać samodzielne lub wspomagane wzmocnienie zdolności mniejszych przedsiębiorstw do autonomicznego generowania wartości [podkr. - B.G.]. Identyfikacja działań służących do realizacji tego celu będzie ułatwiona dzięki operacjonalizacji pojęcia „trudność sytuacji przedsiębiorstwa” z punktu widzenia możliwości generowania wartości i ustalenia 
wymiarów sytuacji przedsiębiorstwa ze względu na łatwość samodzielnego generowania wartości.

Przeprowadzone przez autora artykułu (Gulski, 2017) jakościowe badania empiryczne nad zjawiskiem zawłaszczania wartości pozwoliły zidentyfikować czynniki o charakterze endogenicznym, które stanowią wymiary „trudności sytuacji przedsiębiorstwa" i tym samym wywołują przymus wchodzenia w relacje $\mathrm{z}$ innymi przedsiębiorstwami $\mathrm{w}$ celu wygenerowania i zatrzymania wartości w pożądanych rozmiarach. Wywiady przeprowadzone z członkami kierownictw kilku przedsiębiorstw pozwoliły stwierdzić, że występują trzy kluczowe wymiary opisujące sytuację przedsiębiorstwa $\mathrm{z}$ punktu widzenia trudności generowania wartości i zarazem konieczności wchodzenia w relacje $\mathrm{z}$ innymi podmiotami: stopień specjalizacji przedsiębiorstwa, charakter aktywności w łańcuchu wartości i stopień dostosowania zasobów przedsiębiorstwa do prowadzonej działalności. W trakcie wywiadów ustalono również, w jaki sposób, w każdym z przedsiębiorstw, charakter sytuacji wpłynął na konieczność wchodzenia przez nie $\mathrm{w}$ relacje $\mathrm{z}$ innymi podmiotami. Uogólnione wnioski z wywiadów dotyczących omawianych zagadnień przedstawiono na rysunku 5.

Przyjęcie założenia, iż każdy z wymiarów może przyjmować duże lub małe natężenie, pozwala, uwzględniając analizowane czynniki, zidentyfikować i opisać osiem różnych sytuacji, w jakich może znaleźć się przedsiębiorstwo. Na rysunku 5 zaprezentowano wpływ stopnia trudności sytuacji przedsiębiorstwa (oznaczonej A-H) opisanej za pomocą wskazanych powyżej wymiarów na przymus (konieczność) wchodzenia przez przedsiębiorstwo w relacje z innymi podmiotami w celu generowania wartości. Na rysunku 5 stopień trudności sytuacji przedsiębiorstwa maleje wraz z przesuwaniem się w prawo. Z malejącym stopniem trudności sytuacji przedsiębiorstwa maleje przymus (konieczność) wchodzenia w relacje z innymi podmiotami, co oznacza, że mniejsza trudność sytuacji przedsiębiorstwa wpływa na większą łatwość samodzielnego generowania wartości, a tym samym mniejsze narażenie na zachowania nieetyczne innych przedsiębiorstw. 


\begin{tabular}{|c|c|c|c|c|c|c|c|c|}
\hline 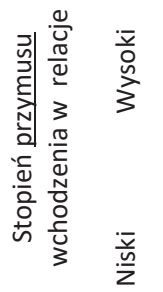 & & & & & & & & \\
\hline $\begin{array}{l}\text { Trudność } \\
\text { sytuacji }\end{array}$ & Duża & & & & & & & Mała \\
\hline Sytuacja & A & B & C & D & E & $\mathbf{F}$ & G & $\mathrm{H}$ \\
\hline $\begin{array}{l}\text { Stopień } \\
\text { specjalizacji }\end{array}$ & $\mathrm{N}$ & W & $\mathrm{N}$ & W & $\mathrm{N}$ & W & $\mathrm{N}$ & W \\
\hline $\begin{array}{l}\text { Charakter } \\
\text { aktywności } \\
\text { w łańcuchu } \\
\text { wartości }\end{array}$ & WO & WO & $C t$ & $C t$ & WO & WO & $C t$ & $C t$ \\
\hline $\begin{array}{l}\text { Dostosowanie } \\
\text { zasobów }\end{array}$ & 0 & 0 & 0 & 0 & Z & Z & Z & Z \\
\hline
\end{tabular}

Rysunek 5. Zależność stopnia przymusu wchodzenia w relacje z innymi podmiotami od trudności sytuacji przedsiębiorstwa

Stopień specjalizacji: $N$ - niski, $W$ - wysoki.

Charakter aktywności w łańcuchu wartości: $W O$ - w wybranych ogniwach, $C £-$ w całym łańcuchu.

Dostosowanie zasobów (do działalności): $O$ - ograniczone, $Z$ - znaczne.

Źródło: opracowano na podstawie Gulski, 2017, s. 304.

Wnioski, które wynikają z analizy rysunku 5, mogą być wykorzystane do podejmowania przez mniejsze przedsiębiorstwa działań antycypujących zachowania nieetyczne większych podmiotów, z którymi zamierzałyby nawiązać relacje. Ograniczenie prawdopodobieństwa takich zachowań przyczyniłoby się do zmniejszenia zagrożenia realizacji CZR. Wydaje się, że mniejsze przedsiębiorstwa powinny co najmniej:

(1) Zidentyfikować i ocenić swoją sytuację, zarówno aktualną, jak i antycypowaną, z punktu widzenia omówionych powyżej wymiarów.

(2) Opracować koncepcję działań, których podstawowym celem byłaby poprawa sytuacji przedsiębiorstwa tak, by jak najbardziej zbliżyła się do sytuacji oznaczonej jako $\mathrm{H}$ na rysunku 5.

(3) Samodzielnie lub we współpracy z innymi podmiotami zrealizować działania określone w punkcie 2 .

Należy podkreślić potrzebę tego, by podczas doboru podmiotów do współpracy w trakcie realizacji koncepcji działań z punktu 2, zwrócić uwagę na cechy potencjalnych partnerów. Wydaje się, że najbardziej pożądanymi byłyby podmioty 
powołane przez samorządy terytorialne, instytucje non profit czy dofinansowywane ze środków organizacji międzynarodowych, filantropów albo, jak w przypadku Unii Europejskiej, z tzw. środków pomocowych. W przypadku nawiązywania relacji z przedsiębiorstwami pożądanym jest zgromadzenie informacji na temat historii ich wcześniejszych relacji, ewentualnych zachowań nieetycznych, postępowań sądowych czy przed specjalnymi instytucjami, np. organami antymonopolowymi. Istotną przesłanką wskazującą na stopień zagrożenia zachowaniami nieetycznymi byłyby wypowiedzi lub inne deklaracje świadczące o tym, czy podmiot - kandydat do nawiązania relacji kieruje się etyką biznesu czy etyką w biznesie. Wydaje się, że z punktu widzenia uniknięcia zachowań nieetycznych odpowiednimi byłyby przedsiębiorstwa cechujące się podobną sytuacją i niemające przewagi negocjacyjnej nad rozpatrywanym przedsiębiorstwem.

\section{Podsumowanie}

Analiza omówionych powyżej CZR i zadań wynikających z nich pozwala dostrzec, że w stosunku do dużych przedsiębiorstw formułowanych jest wiele oczekiwań, dlatego ich postępowanie ma znaczący wpływ na realizację omawianych celów i zadań, ale zarazem stwarza tym przedsiębiorstwom możliwości podejmowania zachowań egoistycznych, motywowanych chęcią zrealizowania przede wszystkim własnych celów. Natomiast dla realizacji CZR ważne jest, by relacje nawiązywane między przedsiębiorstwami miały pewne cechy, przede wszystkim zapewniające sprawiedliwość dystrybutywną współdziałającym przedsiębiorstwom.

Kluczowym celem artykułu było zidentyfikowanie sytuacji sprzyjających nieetycznym zachowaniom przedsiębiorstw, do których może dochodzić w związku z CZR, będących zarazem potencjalnym zagrożeniem dla ich realizacji, oraz wskazanie takich cech małych i średnich przedsiębiorstw, które ułatwiają podejmowanie wobec nich zachowań nieetycznych. Aby zrealizować cele artykułu, określono te CZR, których realizacja jest uzależniona od nawiązania relacji między przedsiębiorstwami. Stwierdzono, że urzeczywistnienie tych celów z reguły służy poprawie sytuacji małych i średnich przedsiębiorstw, zaś ich osiągnięcie zwykle odbywa się w ten sposób, że duże czy silniejsze pod jakimś względem przedsiębiorstwa współdziałają z mniejszymi przedsiębiorstwami, nawiązując z nimi relacje i włączając je w swoje łańcuchy wartości lub ułatwiając im samodzielne generowanie i zatrzymywanie wartości. Większe przedsiębiorstwa, w trakcie takich relacji, mogą znaleźć się w sytuacji dylematu moralnego: ulec presji finansjalizacji oraz innych czynników i kierować się tylko własnym interesem czy w swoich zachowaniach uwzględniać również interesy podmiotów pozostających z nimi w relacjach (co opisuje 
dylemat - etyka biznesu czy etyka w biznesie)? Konsekwencją wyboru pierwszej z wymienionych opcji może być podejmowanie zachowań nieetycznych w celu zwiększenia wielkości wartości, którą przedsiębiorstwo może zatrzymać.

Przeprowadzone analizy pozwoliły określić, jakie zachowania przedsiębiorstw można uznać za nieetyczne. Stwierdzono, że zachowania nieetyczne mogą być podejmowane głównie przez przedsiębiorstwa, które w relacjach z otoczeniem kierują się podejściem etyka biznesu.

Jak wykazano w tekście, takie zachowania większych przedsiębiorstw stanowią zagrożenie dla realizacji CZR.

$\mathrm{W}$ artykule wskazano również kluczowe cechy mniejszych przedsiębiorstw, które ułatwiają podejmowanie wobec nich zachowań nieetycznych, co winno posłużyć określeniu, w jaki sposób mogą one bronić się przed takimi zachowaniami innych przedsiębiorstw. Świadomość istnienia takowych właściwości przedsiębiorstwa, które narażają je na zachowania nieetyczne innych podmiotów, jest podstawą do inicjowania i wdrażania zmian ograniczających lub eliminujących uzależnienie od innych podmiotów. Może to przyczynić się do zwiększenia stopnia realizacji przynajmniej niektórych CZR.

$\mathrm{W}$ artykule skupiono się na nieetycznych zachowaniach przedsiębiorstw, ale należy podkreślić, że podejmowanie przez duże przedsiębiorstwa zachowań etycznych, może - zgodnie z regułą win-win - doprowadzić do skutków korzystnych dla obu stron relacji, a jednocześnie umożliwić realizację CZR.

Jakkolwiek w publikacji nie zajmowano się tematyką współczesnych ideologii czy paradygmatów zarządzania, jako kierunek dalszych badań czynników wpływających na realizację CZR można wskazać wpływ koncepcji wartości dla akcjonariuszy i interesariuszy na ich osiągnięcie.

\section{Bibliografia}

II posiedzenie Grupy Roboczej EKZZ ds. Agendy 2030 i celów zrównoważonego rozwoju ONZ, opzz, Aktualności, Porozumienie, Wydarzenia/25 stycznia 2019. Pobrane z: www.kadra.org.pl/grupa-robocza-ekzz-ds-zrownowazonego-rozwoju (22.06.2020).

Bernatt, M. (2011). Sprawiedliwość proceduralna w postępowaniu przed organem ochrony konkurencji. Warszawa: Wydawnictwo Naukowe Wydziału Zarządzania Uniwersytetu Warszawskiego.

Bourdieu, P. (2008). Zmysł praktyczny (tłum. M. Falski). Kraków: Wydawnictwo Uniwersytetu Jagiellońskiego. 
Dembinski, P. H. (2012). Ethic and the Economy: A Tense Relationship. W: C. Cosgrove-Sacks, P. H. Dembinski (red.), Trust and Ethics in Finance, Innovative Ideas from the Robin Cosgrove Prize (s. 31-42). Geneva: Globethics.net.

Dembinski, P. H. (2017). Etyka i odpowiedzialność w świecie finansów (tłum. L. Kamiński). Warszawa: Wydawnictwo Studio Emka.

Fung, V. K., Fung, W. K., Wind, Y. (J.) (2008). Konkurowanie w plaskim świecie (tłum. A. Ehrlich). Warszawa: Wyższa Szkoła Przedsiębiorczości i Zarządzania im. Leona Koźmińskiego.

Gulski, B. (2017). Zjawisko zawłaszczania wartości a zachowania obronne przedsiębiorstw. Lublin: Wydawnictwo Uniwersytetu Marii Curie-Skłodowskiej.

Lambert, D. M., Pohlen, T. L. (2001). Supply Chain Metrics. International Journal of Logistics Management, 12(1), 1-19.

Lambin, J. J. (2001). Strategiczne zarządzanie marketingowe (tłum. J. Adamczyk). Warszawa: Wydawnictwo Naukowe PWN.

Lazonick, W. (2017). The New Normal is "Maximizing Shareholder Value": Predatory Value Extraction, Slowing Productivity, and the Vanishing American Middle Class. International Journal of Political Economy, 46, 217-226.

Lissowski, G. (2008). Zasady sprawiedliwego podziału dóbr. Warszawa: Wydawnictwo Naukowe „Scholar”.

Machura, P. (2011). Normy moralne, ideały i supererogacja. Folia Philosophica, 29, 277- 305.

Mazzucato, M. (2021). Wartość wszystkiego. Wytwarzanie i zawłaszczanie w globalnej gospodarce (tłum. J. Bednarek). Poznań: Wydawnictwo Ekonomiczne Heterodox.

Nirmalya, K. (1996). The Power of Trust in Manufacturer-Retailer Relationships. Harvard Business Review, 11-12. Pobrane z: https://hbr.org/1996/11/the-power-of-trust-in-manufacturer-retailer-relationships (21.05.2018).

Pérez, L., Cambra Fierro, J. J. (2018). Value Creation and Appropriation in Asymmetric Alliances: The Case of Tech Startups. M@n@gement, 21(1), 534-573.

Progress Towards the Sustainable Development Goals, Raport Sekretarza Generalnego ONZ E/2017/66 z 11 maja 2017 r. Pobrane z: www.un.org/development/ desa/publications/sdg-report-2017.html (11.10.2019).

Sternberg, E. (1998). Czysty biznes. Etyka biznesu w działaniu (tłum. A. Łuków). Warszawa: Wydawnictwo Naukowe PWN.

United Nations Global Compact. Pobrane z: ungc.org.pl/sdg/sustainable-develompent-goals (15.05.2019).

Young, H. P. (2003). Sprawiedliwy podział (tłum. J. Haman, M. Jasiński). Warszawa: Wydawnictwo Naukowe „Scholar”.

Zawadzki, M. (2014). Nurt krytyczny w zarzadzaniu. Kultura, edukacja, teoria. Warszawa: Wydawnictwo Akademickie SEDNO. 
